\title{
Arkeolojik Hayvan Dışkısı Çalışmalarına Çok-Göstergeli Yaklaşım: Orta Anadolu, Akeramik Neolitik Dönem Yerleşmesi Aşılklı Höyük’ten Yeni Bulgular
}

\section{Multi-Proxy Approach to Archaeological Dung Research: New Evidence from Aceramic Neolithic Site of Aşıklı Höyük, Central Anatolia}

\author{
Melis Uzdurum¹ (), Güneş Duru² (1)
}

'Ondokuz Mayıs Üniversitesi, Arkeoloji Bölümü, Samsun, Türkiye

2Mimar Sinan Güzel Sanatlar Üniversitesi, Kültür Varlıklarını Koruma ve Onarım Bölümü, Istanbul, Türkiye

ORCID ID: M.Ü. 0000-0002-3623-0874; G.D. 0000-0003-1870-0120

Sorumlu yazar/Corresponding author: Melis Uzdurum (Dr.)

Ondokuz Mayıs Üniversitesi, Arkeoloji Bölümü, Samsun, Türkiye

E-posta: muzdurum@gmail.com

Başvuru/Submitted: 12.04 .2021

Kabul/Accepted: 29.05 .2021

Atıf/Citation: Uzdurum, M., \& Duru, G. (2021). Arkeolojik hayvan dışkısı çalıșmalarına çokgöstergeli yaklaşım: orta anadolu, akeramik neolitik dönem yerleşmesi Aşıklı Höyük'ten yeni bulgular. Anadolu Araştırmaları-Anatolian Research, 24, 33-66.

https:/doi.org/10.26650/anar.2021.24.914913

\section{öz}

Hayvan dışkısı hem çevresel koşullar hem de insan topluluklarının yaşamına ve geçmişte insan-hayvan etkileşimine dair bilgi sağlayan disiplinlerarası çalışmaların ilgi odağındaki araştırma alanlarından biridir. Arkeolojik yerleşmelerdeki hayvan dışkısı kalıntılarının makroskopik olarak tespit edilmesi çoğu zaman mümkün değildir. Bu nedenle özellikle son yıllarda dışkının mikro göstergelerine ulaşabilmenin yollarına odaklanan araştırmalar artmış, çeşitlenmiştir. Çalışmamız çok-göstergeli yaklaşım (multi-proxy approach) çerçevesinde yapı malzemelerindeki hayvan dışkısının izlerini belirlemenin analitik yollarına odaklanmaktadır. Bu bağlamda Akeramik Neolitik Dönem yerleşmesi Aşıklı Höyük'teki kerpiç ve harçlar üzerinde ince kesit analizleri, kalsiyum karbonat $\left(\mathrm{CaCO}_{3}\right)$, karbon $(\mathrm{C})$ ve azot $(\mathrm{N})$ analizleri gerçekleştirilmiştir. Mikromorfoloji/ince kesit analizleri sözü edilen göstergelerden birinin dışkı sferülitleri olduğunu ortaya koymuştur. Hayvan dışkısının göstergelerinden bir diğerinin ise azot olduğu anlaşımıştır. Böylelikle ulaştığımız sonuçlardan biri iskan boyunca kerpiç yapı geleneğini hiç terk etmemiş bir topluluk olan Aşıklııların kerpiç ve harçlarında katkı malzemesi olarak hayvan dışkısı kullandığı; diğeri bu kullanımın yerleşik köy yaşamının kurulduğu süreçte hem zamansal değişime, hem de mekansal çeşitliliğe sahne olduğudur. Buradan çıkarımla çalışmamız arkeolojik hayvan dışkıına dair bilgimizin sınırlarını çokgöstergeli yaklaşım ve yöntemlerle genişletebileceğimizi ortaya koymaktadır. Anahtar Kelimeler: Tarihöncesi, Yapı Malzemesi, Kerpiç, Mikromorfoloji, Azot

\section{ABSTRACT}

Dung is one of the most important research areas of interdisciplinary studies, which can provide insights into the lives of past communities, environmental conditions, and human-animal interactions. In archaeological contexts, animal dung cannot be identified macroscopically in most cases. Hence, new methods and approaches focusing on ways to describe the micro-markers of dung have increased and diversified over the last decade. This study used a multi-proxy approach focusing on analytical methods to identify the markers of animal dung in prehistoric construction materials. Micromorphology/thin section analysis, and calcium 
carbonate $\left(\mathrm{CaCO}_{3}\right)$, carbon $(\mathrm{C})$, and nitrogen $(\mathrm{N})$ analyses were carried out on mudbricks and mortar from the Aceramic Neolithic site of Aşıkı Höyük. Thin section analysis suggested that fecal spherulites are one of the most important proxies of archaeological dung. Nitrogen is the other indicator of animal dung. The results showed that the Aşıklı inhabitants did not abandon mudbricks in their architectural needs for decades and used animal dung as a temper in mudbricks and mortar. Throughout the centuries of occupation at the site, the use of animal dung as a temper changed both diachronically and spatially, particularly with the establishment of settled village life at Aşıklı Höyük. In conclusion, this study suggests that the limits of knowledge of archaeological dung can be expanded using a multi-proxy methodological approach.

Keywords: Prehistory, Construction Material, Mudbrick, Micromorphology, Nitrogen

\section{EXTENDED ABSTRACT}

People living in various geographies of the world, especially in rural areas, use animal dung for manuring, fuel, and lighting. Dung is known to have a tempering and binding effect in construction materials such as mudbrick and is still a preferred material in building construction. Archaeological studies and analyses on dung have the potential to yield data on past livestock practices including foddering, and penning, as well as its use as fuel. The study of archaeological dung, thus, provides insights into past cooking activities and food production, production technologies of construction materials and space use, animal movements, and the management and domestication of animals. From a methodological point of view, macro-archaeological analyses often prove to be insufficient to identify dung remains, thus requiring the application of micro-scale analyses to identify dung markers and remains in soils and sediments. In recent years, new microarchaeological methods have been developed in this research area and high-resolution analyses are applied.

In this study, the use of animal dung as a temper in the production of construction materials at Aşıklı Höyük (8350-7300 cal BCE, Volcanic Cappadocia) is studied through microarchaeological methodologies, including thin section analyses and calcium carbonate $\left(\mathrm{CaCO}_{3}\right)$, carbon $(\mathrm{C})$ and nitrogen $(\mathrm{N})$ analyses. This study aims to identify animal dung in mudbricks and mortars at the site using a combination of observable analyses (micromorphology/thin section analysis) and quantitative analyses (calcium carbonate, carbon, and nitrogen) and to identify the proxies of archaeological dung according to the analytical results obtained. Thus, we aim to contribute to current studies on prehistoric dung and to the development of new methods and approaches in determining markers of archaeological dung in archaeological contexts.

Observable and quantitative analyses reveal certain markers to identify dung in mudbricks and mortars at Aşıklı Höyük. These proxies are fecal spherulites and chemical elements. Spherulites are the direct evidence of dung and therefore constitute the first micro-data group of this study. Fecal spherulites identified under the microscope with thin section analysis and their micro-contextual distribution suggest the extensive use of dung as temper in mortars. We have also observed some diachronic changes in dung use. The partial increase of dung 
temper in mortars in early- $8^{\text {th }}$ millennium BCE contexts at the site corresponds with the expansion of penning areas within the settlement. In contrast, there is a distinct lack of fecal spherulites in mudbricks and mortars during the mid- $8^{\text {th }}$ millennium BCE, when the on-site penning areas disappeared, and the settlement was divided into two main functional areas (the dwelling area and the special purpose buildings area).

The decrease in the percentage of organic carbon, carbon, nitrogen, and calcium carbonate in mudbricks and mortars during the mid- $8^{\text {th }}$ millennium BCE is coherent with the thin section results. On the other hand, the fact that the percentage of organic carbon and nitrogen in mudbricks is relatively higher in the special purpose buildings area (SPBA), and also the presence of fecal spherulites in one of the thin section samples from this area indicates that dung may have been used as temper in this part of the settlement. However, due to the limited number of samples and the lack of a statistically significant difference in the percentages of organic carbon and nitrogen between the dwelling area and the SPBA, this hypothesis should be further tested with thin section analysis. It is important to increase the number of micromorphology samples from the SPBA to better understand the settlement strategies and architectural choices of the community.

The main pitfall we encountered in thin section analysis was related to the limitations in the number and size of the samples. The data obtained from thin section analysis was cross-checked with quantitative micro-analyses. Nitrogen element analysis confirms the thin section results. Thus, the identification of dung in the thin sections from mudbricks and mortars that we were not able to sample extensively was further supplemented with elemental analyses in a diachronic and spatial scale. This approach provides certain advantages, especially considering the lack of an archaeological thin section laboratory in Turkey, and the financial costs and bureaucratic processes of transferring the samples to laboratories abroad. On the other hand, it should not be overlooked that archaeological micromorphology is one of the most effective methods to identify fecal spherulites and is complementary to elemental analysis. In this sense, the importance of archaeological dung studies with multiproxy approaches that bring together a wide variety of micro-scale analyses within the same research framework comes to the fore. 


\section{Giriş}

Dünyanın çeşitli coğrafyalarında özellikle de kırsal kesimlerde yaşamakta olan pek çok topluluk tarımsal gübreleme, ısınma ve aydınlanmada hayvan dışkısını kullanır. Evlerin zeminini ve duvarlarını sıvamak, kerpiç gibi yapı malzemelerini hazırlamakta katkı ve bağlayıcı etkisi bilinen hayvan dışkısı inşaat işlerinde de halen tercih edilen bir malzemedir. Hayvan dışkısı üzerine yapılan arkeolojik çalışma ve analizler geçmişteki hayvan otlatma uygulamaları, hayvanların beslenme pratikleri, ayrıca toplulukların pişirme faaliyetleri, yapı malzemelerinin üretim teknolojisi gibi araştırma konularına açıklık getirmektedir. $\mathrm{Bu}$ araştırma konuları ve analizler çoğunlukla yeni bir yaşam biçimine geçen Neolitik dönem topluluklarına odaklıdır.

İnsan topluluklarının hayvan dışkısını ne zaman, hangi koşullarda, ne gibi işlerde kullanmaya başladığı arkeologların ilgi odağındaki konulardandır. Arkeolojik çalışmalar 12 bin yıl öncesinden bu yana Güneybatı Asya'da köy tipi yerleşmeleri ilk kuran, toprağ 1 eken, sığır, koyun, keçi ve domuzu evcilleştirilen toplulukların hayvan dışkısını günlük faaliyetlerinde kullandığını ortaya koyar (Brochier, Villa, Giacomarra ve Tagliacozzo, 1992; Portillo, Garcia-Suarez ve Matthews, 2020). Son yıllarda yapılan jeo-etnoarkeolojik araştırmalar ve mikroarkeolojik analizler dışkının hayvan evcilleştirmesinden önce hem yakacak olarak ocaklarda hem de sıva üretiminde katkı malzemesi olarak kullanılmaya başladığına dikkat çekmektedir (Gur-Arieh, Madella, Lavi ve Friesem, 2019) (Ayrıca bakınız Otaegui, Polo-Diaz ve Richter, 2017¹).

Hayvan dışkısının organik kısımları çok hızlı bir şekilde mikroorganizmalar tarafından yok edilir ve dışkıdan geriye yalnızca mineral bileşenler (fitolitler ve sferülitler) kalır (ShahackGross, 2011, s. 206; Weiner, 2010, s. 233). Bu bakımdan hayvan dışkısı her ne kadar geçmişi açıklayıcı etkin bir role sahip olsa da bir o kadar ulaşılması güç kalıntılardır. Makro-botanik kalıntıların analizi, arkeolojik yerleşmelerdeki hayvan dışkısının tanımlanmasında oldukça kullanışlıdır (Spengler, 2019). Ancak bu tanımlamaların yapılabilmesi için bitkisel kalıntılar günümüze karbonize halde korunagelmiş olmalıdır. Oysa ki bitkisel kalıntıların karbonize olmasını gerektirmeyen dışkı kullanım alanları da mevcuttur. Örneğin hayvan dışkısı, kerpiç, harç veya çanak çömlek gibi bağlamlarda veya kurumuş kalıntılar aracılığıyla da tespit edilebilmektedir. Söz konusu makroarkeolojik analizler yeterli olmadığında ise toprak ve sedimanlardaki hayvan dışkısının izini sürebilmek için farklı analizlere ihtiyaç duyulur. Son yıllarda bu alanda yeni mikroarkeolojik yöntemler geliştirilmekte ve yüksek çözünürlüklü analizlere başvurulmaktadır. \begin{tabular}{l}
\hline https://core.tdar.org/document/429992/dung-use-before-animal-domestication-in-southwest-asia-evidence- \\
from-early-natufian-shubayqa-1-northeastern-jordan
\end{tabular} 
Hayvan dışkısının birden fazla mikroarkeolojik analiz ile eş zamanlı olarak çok-göstergeli yaklaşımla (multi-proxy approach) ${ }^{2}$ ele alındığ 1 araştırmalar kısıtlıdır (Fuks ve Dunseth, 2021; Gur-Arieh, Mintz, Boaretto ve Shahack-Gross, 2013, Gur-Arieh ve ark., 2014; Lancelotti ve Madella, 2012; Macphail ark., 2004; Portillo ve Albert, 2011; Portillo, Albert ve Henry, 2009; Portillo, Kadowaki, Nishiaki ve Albert, 2014; Shahack-Gross ve ark., 2005; Shillito ve ark., 2011; Simpson, Vésteinsson, Adderley ve McGovern, 2003; Zapata Peña, Peña-Cocarro, Ibáñez Estévez ve González Urquijo, 2003). Yap1 malzemelerindeki hayvan dışkısı kullanımına ilişkin kanıtlar nispeten daha az çalışılmıştır. Var olan çalışmaların büyük çoğunluğu etnoarkeolojik ve jeo-etnoarkeolojik çerçevede ele alınmıştır (Berna, 2017; Boivin, 2000; Friesem, Karkanas, Tsartsidou ve Shahack-Gross, 2014; Goodman-Elgar, 2008; Mbae, 1990; Shahack-Gross, Marshall, Ryan, Weiner, 2004). Doğrudan arkeolojik yap1 malzemeleri üzerinde çok-göstergeli yaklaşım ile gerçekleştirilen hayvan dışkısı çalışmaları ise münferit örneklerden ibarettir (sıvalar için bkz. Karkanas, 2006; Portillo ve ark., 2014; kerpiçler için bkz. Love, 2012; Viklund, Linderholm ve Macphail, 2013).

Bu çalışmada, Volkanik Kapadokya' da Akeramik Neolitik Dönem yerleşmesi olan Aşıklı Höyük’teki yapı malzemelerinde rastlanan hayvan dışkısına ilişkin kanıtlar mikromorfoloji/ ince kesit analizleri, kalsiyum karbonat $\left(\mathrm{CaCO}_{3}\right)$, karbon $(\mathrm{C})$ ve azot $(\mathrm{N})$ analizleri yoluyla incelenmektedir. Çalışmanın amaçlarından biri yerleşmedeki kerpiç ve harçlardaki hayvan dışkısı kalıntılarını hem gözlemlenebilir (mikromorfoloji/ince kesit analizleri) hem de ölçülebilir (kalsiyum karbonat, karbon ve azot) mikro analizler kullanarak değerlendirmek, bir diğeri elde edilen analitik sonuçlara göre hayvan dışkısının göstergelerini belirlemektir. Böylelikle tarihöncesi hayvan dışkısına dair bilgimizin yelpazesini genişletmeyi ve bu araştırma alanının gelecekte daha da gelişmesini sağlayabilecek potansiyel yolların belirlenmesine yeni yöntem ve yaklaşımlarla katkı sağlamayı hedeflemekteyiz.

\section{Arkeoloji Bilimlerinde Hayvan Dışkısı Araştırmaları}

Hayvan dışkısı, makroarkeolojik çalışmalarla tanımlanması zor olan kalıntılardır. Gelişen yeni yaklaşım, yöntem ve tekniklerle bu güçlügün üzerinden gelen arkeologlar, hayvan dışkısının izini sürmenin birden çok yolunu bulmuştur. Arkeolojik dolgu ve tortularda hayvan dışkısının izini belirlemenin en güvenilir yollarından biri kalsiyum karbonatın lifli kristal yapılı kümeleri olan sferülitlerin incelenmesidir (Canti ve Brochier, 2017; Canti, 1997,

2 Multi-proxy terimi arkeolojide bir araştırma sorusunu cevaplayabilmek için birden fazla göstergeyi aynı anda kullanan, sorgulayan ve bunları birbirleriyle ilişkilendiren yaklaşımı tanımlamak için kullanılmaktadır (Shillito, 2017). Göstergeler arasındaki ilişkiyi eksiksiz olarak kurabilmek ve mikro bağlamlar arasındaki boşluğu tamamlayabilmek amacıyla arkeolojik kalıntılar birden fazla mikro ve makro analiz bir araya getirilerek incelenir. Örneğin Shahack-Gross ve meslektaşları (2005) Tel Dor yerleşmesinin (İsrail) mekan tabanlarındaki çeşitli sıva yenilemelerinin karakterizasyonunu belirleyebilmek için yapmış oldukları bir çalışmada ince kesit, fitolit ve FTIR spektroskopisi analizleriyle mikromorfolojik, mikro-botanik ve mineralojik göstergeleri bir araya getirmiştir. Bu nedenle multi-proxy approach teriminin Türkçeye "çok-göstergeli yaklaşım" olarak çevrilmesini öneriyoruz. 
1999). Sferülitler hayvan dışkısının doğrudan bir göstergesidir. Dışkı sferülitleri genellikle koyun, keçi, sığır veya geyik gibi geviş getiren hayvanların bağırsaklarında bulunan, 5-15 mikron büyüklüğündeki mineral küreciklerdir ${ }^{3}$. Kürecikler arkeolojide mikromorfoloji yöntemiyle, kalıntıların ince kesitlerinin incelenmesi yoluyla doğrudan tanımlanabilirler. Etobur ve domuz, kedi, tilki, insan gibi hepçil türlerde çok az bulunur; at ${ }^{4}$, tavşan ve yabani tavşanlarda ise hiç görülmez. Sferülitler kalsiyum karbonattan oluşmaktadır, yanmış olsalar bile mikroskop altında tanımlanabilirler; çok nemli veya $\mathrm{pH}$ derecesi düşük koşullarda ise çözünürler. Arkeolojik dolgular içindeki kalsiyum karbonat birikintileri dışkının doğrudan bir göstergesi olsa da bunların yokluğu, incelenen arkeolojik dolgu ve malzeme içerisinde dışkı bulunmadığı anlamına gelmez (Konu hakkında yapılan deneysel çalışmalar için bkz. Lancelotti ve Madella, 2012).

Arkeolojide hayvan dışkısını tanımlamanın bir diğer yolu dışkıdan geriye kalan kimyasal elementlerin analiz edilmesi esasına dayanır. Bu elementlerden karbon, kalsiyum, azot, fosfor ve sodyum hayvan dışkısına dair ipucu niteliği taşırlar. Fosfor (P), toprakta yüksek miktarda bulunduğunda gübrelemeyi ya da hayvan dışkısı olduğunu düşündürür (Simpson, Dockrill, Bull ve Evershed, 1998). Diğer yandan, yapılan deneysel bir çalışma topraktaki fosfor seviyesinin sadece hayvan dışkılamasına bağlı olarak artmadığını, fosforun kumlu topraklar gibi fosfat reseptörleri bulunmayan türdeki topraklardan doğal yollarla sızabileceğini ortaya koymuştur (Crowther, 2002). Benzer şekilde karbon (C), kalsiyum (Ca), azot (N) da hayvan dışkısının göstergelerindendir. Bazı deneysel çalışmalar bu elementlerin toprakta uzun süre korunamaması nedeniyle dışkının doğrudan tespitinde yetersiz kaldığını göstermiş olsa da (Evershed, Bethell, Reynolds ve Walsh, 1997), element analizlerinin fitolit, mikromorfoloji gibi analizlerle birlikte değerlendirildiğinde tamamlayıcı bir rol üstlendiği anlaşılmaktadır (Shahack-Gross, 2011). Ayrıca hayvanların kontrolü ve tarımsal gübrelemenin belirlenmesi için arkeobotanik kalıntılar üzerinde azot izotop $(\delta 15 \mathrm{~N})$ analizleri gerçekleştirilmiş ve başarılı sonuçlar alınmıştır (Bogaard, Heaton, Poulton ve Merbach, 2007).

Fosfat ve diğer elementlerin izine rastlanmadığı durumlarda, koprostanol, safra asidi, mikroorganizmalar ve bağırsak parazitleri gibi hayvan dışkısına dikkat çeken biyogöstergelere yönelinir. Bunlardan biri sedimanlardaki 5 $\beta$-stanol'un varlığıdır (Evershed ve ark., 1997).

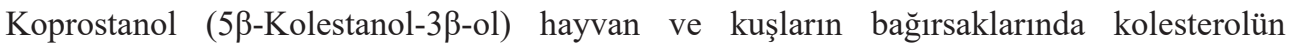
mikrobiyal aktivitesi yoluyla oluşur ve kil oranı, sıcaklık ve ortamın sediman özelliklerine göre korunabilirler. Bağırsak paraziti yumurtaları (Schelvis, 1992) ve dışkıya özgü mantarlardan elde edilen sporlar (van Geel, 2001) ise sözünü ettiğimiz diğer biyogöstergelerdir.

3 Dışkı sferülitleri mikroskopta XPL modda, yüksek çözünürlükte kolaylıkla ayırt edilebilirler. Ancak kokolit adı verilen tek hücreli yosunların oluşturduğu tabakalar ve kuş idrarı gibi bazı mikroskobik öğelerle dışkı sferülitlerinin benzer morfolojik karaktere sahip olduğu not edilmelidir. Ayrıca ince kesit hazırlı̆̆ı sırasında yapılan bazı teknik hatalar morfolojik tanımlamaların yapılmasına engel oluşturabilmektedir (Canti, 1998, s. 442). 
Son olarak bitkinin çeşitli organ ve bölümlerinin ardında bıraktığg silika izleri de hayvan dışkısının arkeolojik alanlardaki belirleyicilerindendir. $\mathrm{Bu}$ silika izlerini tespit etmek için fitolit analizlerine başvurulur (Piperno, 2006; Shahack-Gross ve ark., 2005). Fitolit analizleriyle dışkı kalıntıları tespit edilebildiği gibi, dışkının ait olduğu tür de tespit edilebilmektedir (Eksambekar ve Kajale, 2007). Ne var ki bu alandaki çalışmalar henüz tartışmalıdır (Shahack-Gross ve ark., 2005).

Dışkının fosilleşmiş haline "koprolit" denir. Koprolitler toynaklı hayvanlara veya insanlara ait olabilir. Kuş, yarasa ve fok türlerinin dışkıları ise "guano" olarak isimlendirilmektedir. Tümü arkeolojinin incelediği dışkı kalıntıları arasında yer alır (Shillito ve ark., 2011).

Arkeolojide hayvan dışkısı üzerine sürdürülen en erken sistematik çalışmalara bakıldığında dışkı kalıntılarının 1980'lerde makrobotani (Miller, 1984), 1990'larda ise mikromorfolojinin (Brochier ve ark., 1992) ilgi alanına girdiği görülmektedir. 1980’lerde Miller ve çalışma ekibinin İran'daki MÖ 3. binyıl toplulukları üzerine yaptıkları botanik çalışmalar yayınlanır. Araştırmacılar bazı tohumların yerleşmeye hayvan dışkısıyla geldiğini ve bunların ocak ya da firınlarda yakıldığında kömürleştiğini, kömürleşen dışkının ise botanik çalışmalarla arkeolojik bağlamında yorumlanabileceğini vurgular (Spengler, 2019, s. 215). Yine Brochier ve çalışma ekibinin (1992) Sicilya'daki açık hava yerleşmelerinin dolgularında ve doğal kaya sığınaklarındaki dolguları inceledikleri etnoarkeolojik çalışmalar bulunmaktadır. Bu erken çalışmalarda hayvan dışkısı parçacık boyu ve fosfat analizleri ile birlikte değerlendirilir. Dışkı kalıntıları üzerine yapılan mikromorfoloji çalışmaları ise ilk sırtlanlarla başlamış (Horwitz ve Goldberg, 1989), ardından popüler bir yöntem haline gelmiştir (örneğin Canti, 1997; Courty, Macphail ve Wattez, 1991).

Son yıllarda hayvan dışkısı üzerine yapılan arkeolojik çalışmalar disiplinlerarası çalışmalar ve çok-göstergeli yaklaşımlarla çok çeşitli mikroarkeolojik yöntemleri kapsayan bir boyut kazanmıştır. Bu çalışmalar artık mümkün olduğunca çok ve çeşitli araştırma alanlarının bir araya getirildiği, geniş coğrafyaları kapsayan projelerle yol almaktadır. Bunlardan biri olan MICROARCHAEODUNG (2016-2018) Güneybatı Asya ve Kuzey Afrika'daki prehistorik topluluklara odaklı gerçekleştirilmiş bir projedir (Portillo, Garcia-Suarez ve Matthews, 2020). Sonuçlar bölgedeki geçmiş toplulukların erken tarım uygulamaları, hayvan evcilleştirme, yakacak kullanımı, yiyecek tedarik etme ve tüketimine dair sonuçlar vermiştir ${ }^{5}$. Bir başka güncel araştırma yine Güneybatı Asya Neolitik topluluklarına odaklı olan MapDung (2018-2020) projesidir. Bu projede insan-hayvan-çevre ilişkileri ve paleoçevreyi anlamak için yapı malzemeleri içerisindeki hayvan dışkısı yeni yöntem ve analizlerin yardımıyla incelenmektedir6.

5 https://cordis.europa.eu/article/id/240562-integrated-investigation-of-livestock-dung-in-archaeology

6 https://cordis.europa.eu/project/id/794823 


\section{Çalışmanın Arka Planı: Aşıklı Höyük}

Aşıklı Höyük, Aksaray il merkezinin 25 km güneydoğusunda, Kızılkaya köyünün yaklaşık 1 km güneyinde, Melendiz nehri kıyısında yer almaktadır. 120'nin üzerindeki radyokarbon tarihlendirme sonucu Aşıklı'nın kesintisiz olarak MÖ 8350-7300 yılları arasında iskan edildiğini gösterir (Quade, Stiner, Copeland, Clark ve Özbaşaran, 2018) (Şek. 1).

Aşıklı'nın ilk sakinlerinin yaşamı birbirinden bağımsız, toprağa yarı gömük, tek odalı, oval planda inşa edilmiş kerpiç duvarlı yapılar içerisinde; ancak daha yoğun olarak hava koşullarının elverdiği ölçüde bu kerpiç barınakların arasına konumlandırılmış açık alanlarda sürdürülmüştür (Özbaşaran ve ark., 2018). Yaşamın ortak açık alanlarda geçtiğinin göstergelerinden biri olan pişirme çukurları, çaytaşı döşeli ocaklar veya küllü alanlar gibi birbirinden farklı nitelikteki çok sayıda ateş yeri açık alanlardaki besin hazırlığı, pişirmeye yönelik faaliyetlerin doğrudan kanıtlarını sunmaktadır. Barınaklardaki ocaklar ise domestik ögelerdir (Uzdurum, 2018). Yapılan analizler ateş yerlerinde fıstık, badem ve yapraklarını döken meşe ağaçlarının (Bourguet, 2015) yanı sıra hayvan dışkısının (Mentzer, 2018) yakacak olarak kullanıldığını ortaya koymuştur.

Saz ile örüldükten sonra üstü çamurla sıvanmış, zemin üstü, oval planlı kulübe tarzı yapılar da yerleşmenin bu erken evrelerinde çeşitli gündelik faaliyetlerin mekanı olmuş ancak kerpiç barınaklardan daha farklı işlevlendirilmişlerdir (Özbaşaran, Duru ve Uzdurum, 2018). $\mathrm{Bu}$ kulübelerden biri az sayıda yeni doğmuş ya da genç koyun/keçiyi kontrol altında tutmak için ayrılmıştır (Kalkan, Özbaşaran ve Özbal, 2020; Mentzer, 2018; Stiner ve ark., 2014; Tsartsidou, 2018; Zimmerman, Pöllath, Özbaşaran ve Peters, 2018). İnce kesit analizleri ile çok kalın bir tabaka halinde mekanın tümüne yayılmış olan ve üst üste yığılarak biriken hayvan dışkısı düzlemlerine ulaşılmıştır (Mentzer, 2018). Mikromorfoloji çalışmaları 9. binyılın ikinci yarısında hayvanların kontrol altında tutulduğu bu alanların daha fazla koyun/ keçi için genişletildiğini ortaya koyar. Aşıklı'daki ilk yerleşiklerin, hayvanlarını yerleşme içerisinde, barındıkları ve günlük faaliyetlerini sürdürdükleri mekanların oldukça yakınında bulundurması, yerleşik yaşama geçişle birlikte insan-hayvan ilişkisinde yaşanan dönüşümün de bir göstergesi olarak karşımıza çıkmaktadır (Stiner, Bailey, Munro ve Christidou, 2018).

8. binyıla geldiğimizde bu dönüşüm, koyun/keçinin evcilleştirilmesi (Buitenhuis ve ark., 2018) ve hayvan sürülerinin yerleşme dışına çıkarılması ile devam edecektir. Karbon ve azot izotop sonuçları koyun/keçinin artık dağlık alanlar gibi yerleşmeye uzak alanlarda otlatılmaya başladığına işaret eder (Pearson ve ark., 2007, s. 2178). Aşıklı'da idrar tuzu üzerine yapılan analizler topraktaki sodyum miktarında 9. binyıl ortasından 8. binyılın ilk çeyreğine dek 100 kata kadar artış olduğunu, bunun canlı idrarından kaynaklanmış olabileceğini, dolayısıyla koyun/keçinin evcilleştirilme sürecinin düşünülenden çok daha hızlı gerçekleştiğini ortaya koymuştur (Abell ve ark., 2019, s. 7-8). Zamanla, 8. binyılın ilk çeyreğinden sonra idrar 
tuzu miktarında saptanan hızlı düşüş, bu aşamadan sonra hayvanların yerleşme alanından uzaklaştırıldığı varsayımını destekler.

Aşıklı Höyük’te 8. binyıla doğru karşımıza çıkan, yavaş ve aşamalı olarak gerçekleşmiş olan değişimler hayvan evcilleştirmeyle sınırlı değildir. Günümüz köy yaşantısına benzer bir yaşamın kurulduğu bu dönemde yerleşme dokusu bitişik nizamlı, birbirinden dar sokak ve geçitlerle ayrılan, doğrudan zemin üzerine inşa edilmiş dörtgen planlı binalardan oluşur (Esin, 1996; Özbaşaran, 2011; Özbaşaran ve Duru, 2015). 9. binyılın sonuna doğru açık alanlardaki ocaklar ve pişirme çukurları, açık alanların kendisiyle birlikte tamamen ortadan kalkmış; ocaklar plan, konum ve olasılıkla kullanım bakımından dönüşerek dörtgen binaların içerisine taşınmıştır. Hayvan dışkısının yakacak olarak kullanımı devam etmektedir. Ancak bu kullanımın yoğunluğu, yaygınlığı ve zaman içerisinde artış gösterip göstermediği halen üzerinde çalışılmakta olan konulardan biridir.

8. binyılın başında yerleşmede yaşanan olası nüfus artışı, mimari sıkışıklık ve zamanla oluşan bina grupları (Duru, 2013), açık alanlardaki üretim, paylaşım pratiklerinin binaların dam seviyesine ve kimi örneklerde mekan içerisine taşınması diğer değişimlerdendir (Esin ve Harmankaya, 2007; Kalkan ve Özbal, 2018; Kayacan ve Algül, 2019; Özbaşaran ve Duru, 2015). Yerleşmenin terk sürecine doğru tanımlı bina grupları ve mahallelerin oluştuğu bir yerleşim düzeni kurulmuş; yerleşme bu dönemde geniş çakıllı bir yolla ikiye ayrılmıştır. Kuzeyde konut alanı, güneyde ise konum, boyut, plan ve iç öğeler bakımından konut yapılarından farklılık gösteren ve topluluğun paylaşım ve ritüel pratikleriyle ilişkili olarak kullanım gören özel amaçlı yapılar alanı karşımıza çıkar.

Yerleşmede zaman içerisinde yaşanan değişimlere karşın kerpiç ve harç yapı malzemesi olarak kullanılmaya devam etmektedir. Noei’nin (2017) beş binanın kerpiç ve harçları üzerinde gerçekleştirmiş olduğu Hidrometre ve Atterberg limitleri, XRD, SEM-EDX, kalsimetre, kızdırma kaybı, asitle muamele analizleri; tuz, yağ ve protein testleri yap1 malzemelerinin çeşitliliğine işaret eder. Schumacher' in (2017) çöplük, açık alan, bina dolgusu ve bir gömütten alınan örnekleri (19 kesilmiş, 53 gevşek örnek) biyomoleküler (GC-MS), mikromorfolojik (ince kesit) ve spektroskopik (FTIR) olarak incelediği yüksek lisans tezi, yerleşmedeki hayvan dışkısının çoğunlukla otobur hayvanlara ait olduğunu, hepçil (olasılıkla insan) kaynaklı örneklerin ise sınırlı olduğunu göstermiştir. Mentzer'in (2018) yerleşme sakinlerinin kerpiç yapımına dair sınırlı sayıda kerpiç ve harç örneği (13 örnek) üzerinde gerçekleştirmiş olduğu mikromorfoloji analizleri, kerpiçler arasında kompozisyon ve doku bakımından çeşitliliğe ve farklı yerel sediman kaynaklarının kullanıldığına dikkat çeker. Analiz edilen örneklerin birinde kalkerli sferülitlerle birlikte konumlanan bitkisel gözenekler ve fitolitler hayvan dışkısının kerpiçte katkı malzemesi olarak kullanıldığını düşündürmüştür. Uzdurum (2019) doktora tezi kapsamında yapı malzemelerini mikroarkeolojik yöntemler ve üretim zinciri çerçevesinde incelemiştir. Bu çalışmayla Aşıklı'daki kerpiç ve harçların 
sediman kaynağı, katkı malzemeleri ve ezme/karma işlemleri belirlenmiş, iskan süresince birbirinden farklı 11 kerpiç ve 6 harç tarifi uygulandığ 1 sonucuna ulaşılmıştır.

\section{Malzeme ve Yöntem}

\section{Arazi Çalışmaları: Örnekleme aşaması}

Bu araştırma kapsamında mikromorfoloji analizleri için kesilmiş blok örnekler; kalsiyum karbonat, karbon ve azot analizleri için ise gevşek toprak örnekleri toplanmıştır. Örnekler tüm tabaka ve evrelerdeki yapıların duvar iç yüzünden ve duvarların günümüze korunagelen en üst kısmındaki kerpiç ve harçlarından alınmıştır. Mikromorfoloji blokları kesilirken kolay dağılabilen, kırılgan malzemeden oluşan kontekstlerde ya da toprağın çok kuru olduğu durumlarda tıbbi alçı bandajlar tercih edilmiş; diğer durumlarda bloklar asitsiz kağıda sarılarak koli bandıyla sıkıca bantlanmıştır. Kesilmiş bloklar yerleşmenin 4GH alanı (20 örnek) ve 2JK alanı (30 örnek) olmak üzere iki farklı alanın profilleri, halen kazılmakta olan en eski tabakaları (8 örnek) (MÖ 9. binyıl ortaları) (Şek. 2 ve Şek. 3) ve konut alanı yapılarını (12 örnek) (MÖ 8. binyıl) (Şek. 4) içermektedir. Özel amaçlı yapılar alanından bütçe ve zaman kısıtlaması nedeniyle sadece bir adet kesilmiş blok örneği alınabilmiştir.

Blok örneği alınan her konteksten 200 gramı geçmeyecek miktarda gevşek toprak örneği kalsiyum karbonat, karbon ve azot analizleri için toplanmıştır. Söz konusu analizler için eşit miktarda; 68 binadan 75'i kerpiç, 60'^ harç olmak üzere toplam 135 adet gevşek toprak örneği toplanmıştır. Bunlardan 41'i 9. binyıl ortası yapılarına, 13'ü 8. binyıl başına tarihlenir (Şek. 2 ve Şek. 3). 8. binyıl ilk çeyreğinden itibaren işlevsel olarak iki alana ayrılan yerleşmenin konut alanından 49, özel amaçlı yapılar alanından 32 adet gevşek toprak örneği alınmıştır (Şek. 4).

\section{Laboratuvar Analizleri}

\section{Mikromorfoloji}

İnce kesit hazırlığg 1 Tübingen Üniversitesi, Toprak Bilimleri ve Jeoekoloji Laboratuvarı'nda Panagiotis Kritikakis ve Melis Uzdurum tarafindan Courty, Goldberg ve Macphail'in (1989) önerdiği şekilde yapılmıştır. Bloklar $50^{\circ} \mathrm{C}$ 'de kurutulup vakumlandıktan sonra 7:3 oranında hazırlanan MEKP (metil-etil keton peroksit) ile katalize edilmiş polyester reçine ve stiren karışımında sertleştirilmiştir. Örnekler lama sabitlendikten sonra 30 mikron inceliğine getirilmiştir. İnce kesitler $5 \times 8 \mathrm{~cm}$ boyutunda hazırlanmıştır.

İnce kesit mikroskop çalışmaları için 2.5X-20X objektifli, yüksek çözünürlüklü Nikon ve Ziess marka petrografi mikroskobu kullanılmış, ince kesitlerin her biri PPL ve XPL modunda olmak üzere, RGB 4.000 dpi çözünürlükte Nikon Super Coolscan model tarayıcı ile taranmıştır. 


\section{Kalsiyum Karbonat (CaCO3)}

Kalsiyum karbonat $\left(\mathrm{CaCO}_{3}\right)$ analizi, Tübingen Üniversitesi, Toprak Bilimleri ve Jeoekoloji Laboratuvarı, kalsimetre ünitesinde yapılmıştır. $\mathrm{CaCO}_{3}$ hesaplamaları için kalsimetre kullanılmıştır (08.53 Calcimeter, Eijkelkamp, Standard NEN-ISO 10693). Kalsimetre öncesinde kurutulan ve ögütülerek toz haline getirilen toprak \%10 oranında seyreltilmiş hidroklorik asit $(\mathrm{HCl})$ ile tepkimeye sokulmuş ve karbonattan çıkan $\mathrm{CO}_{2}$ gazı hava almayan bir boruda kapalı tutularak hacim ölçülmüştür. Bu hacimden yararlanılarak $\mathrm{CaCO}_{3}$ yüzdesi hesaplanmıştır. Kaç gram toprak kullanılacağı karbonat yoğunluğuna bağlıdır. Bunu anlamak için analiz öncesinde bir miktar örnek, HCI asit dolu cama dökülerek tepkime gözlemlenmiştir. Tepkime (kabarcıklanma) fazla ise analiz için $0.5 \mathrm{gr}$, az ise $2 \mathrm{gr}$ örnek kullanılmıştır. Sonuçların sağlamasının yapılması amacıyla her toprak örneği iki kez analiz edilmiştir.

\section{Karbon (C) ve Azot (N)}

Karbon (C) ve azot (N) element analizleri, Tübingen Üniversitesi, Element ve Piroliz Laboratuvarında, Vario EL III Element Analizörü ile yapılmıştır. Örnekler analiz öncesinde elenmiş ve öğütülerek toz haline getirilmiştir. Analiz esnasında kontrol amaciyla her 10 örnekten 10.'su iki kez analiz edilmiştir. İşlem basamakları sırasıyla, 1) 5 gr sülfanilik asit ile 6 kez standart alma, 2) 3 kez boş değer alınması, 3) 33 örneğin (ilk grup) her birinin 40 mg wolfram (VI)-Oxid ile birlikte ince folyolarda hazırlandıktan sonra ardışık olarak sisteme tanımlanması, 4) 5 mg karşılaştırma sedimanı ile 3 kez kontrol etme, 5) 33 örneğin (ikinci grup) her birinin $40 \mathrm{mg}$ wolfram (VI)-Oxid ile birlikte ince folyolarda hazırlandıktan sonra ardışık olarak sisteme tanımlanması, 6) 5 gr sülfanilik asit ile bir kez standart alma şeklinde gerçekleştirilmiştir. Son adımda hazırlanan folyolar/örnekler numara sırasına göre element cihazına yerleştirilmiştir.

\section{Istatistiki Çalışmalar}

Ölçülebilir mikro analiz sonuçları için temel bileşen analizleri yapılmış, mikro-göstergeler t-test ve ikili korelasyon testleriyle sorgulanmıştır. İstatistiksel çalışmalar $S A S$ uzantılı JMP14 (Pro) istatistik yazılımılla gerçekleştirilmiştir.

Gözlemlenebilir mikro analizlerde (ince kesit analizi) mikroskop çalışmalarında tanımlanan kalıntıların miktarı mikromorfoloji yoğunluk tablosu kullanılarak (Stoops, 2003: 48, Şek. 4.11) tespit edilmiş ve sonuçlar yüzdesel olarak gruplandırılmıştır. Mikro kalıntıların yüzdelik olarak ifade edilmesi dilimler arasındaki fark yüksek olduğundan (\%10-30-60 gibi) istatistiksel analizlerde yanıltıcı dağılım sonuçlarına sebebiyet verebilmektedir. Ayrıca farklı yüzdesel oranların ifade ettiği önem mikro kalıntının içeriğine ve arazinin jeolojik yapısına göre değişkenlik gösterebilmektedir. Bu nedenle ince kesit analizleriyle yoğunluğu belirlenen 
dışkı kalıntılarına 0-4 arasında değer verilerek, hiç=0, az=1, biraz=2, çok=3, baskın=4 şeklinde, ordinal (sıralama) veri oluşturulmuş ve parametrik olmayan çoklu karşılaştırma testleri olan Kruskal Wallis ve Dunn's metoduna başvurulmuştur (Wayne, 1990). Çıkartılan kontrol çizelgelerinin ardından JMP-14 (pro) kullanılarak diyagramlar oluşturulmuştur.

\section{Gözlemlenebilir Mikro Analiz Sonuçları}

\section{Mikromorfoloji}

İnce kesit analizleriyle kerpiç ve harçlarda dışkı sferülitleri, fitolitler, bitkisel gözenekler ve humuslaşmış organik malzemeler tanımlanmıştır (Şek. 5). İncelenen kerpiç ve harç örnekleri sferülit yoğunluğu bakımından birbirinden iki farklı tablo çizer. Kerpiç örneklerinin \%25'i, harçların \%50'si dışkı sferüliti içermektedir. Örneklerdeki agregalar yuvarlak formdadır, ince kesitlerin matrisine göre ince tanelidir. Harçlar kerpiçlerle karşılaştırıldığgnda daha yoğun ve büyük boyutta agrega içermektedir (objektif 2,5x: 20-1400 $\mu \mathrm{m}$ ). Kerpiçlerde agrega oranı \%20'nin altında kalırken, harçlarda bu oran \%10-40 arasında değişmektedir. Gerek kerpiç gerekse harç agregalarında dışkı sferülitlerine rastlanmamıştır. İncelenen örneklerin yalnızca birinde ikincil nitrat tanımlanmıştır. Nitrat, hayvan ya da insan idrarına işaret eder.

D1şk1 sferülitlerinin yoğunluğu kronolojik olarak incelendiğinde, 9. binyılın ikinci yarısına tarihlenen yalnızca dört yapının kerpiçlerinde, yoğun olmamakla birlikte, dışk1 sferüliti olduğu görülmektedir (Şek. 6). Bu örneklerdeki sferülitler, gözenekler içerisinde bulunmakta veya fitolitler ve humuslaşmış organik malzemelerle karışmış halde konumlanmaktadır. Aynı zaman diliminde harçların tamamına yakını dışkı sferüliti içermekle birlikte, bu örneklerdeki sferülit yoğunluğu da fazladır. Harçlardaki dışkı sferülitlerinin bazıları topaklar halinde, bazıları ise üst üste yığılmış şekildedir. Yanmış sferülitler ve fosfat nodülleri de tanımlanmıştır. 8. binyılın ilk çeyreğinde (2GHIJ evreleri) dışkı sferülitlerinin kerpiçlerde azaldığı, harçlarda ise arttı̆̆ 1 gözlemlenmiştir. 8. binyılın ikinci yarısından itibaren (2DEF ve 2ABC evreleri) gerek kerpiç gerekse harçlarda dışkı sferüliti tespit edilmemiştir. İstisnai tek örnek özel amaçlı yapılar alanındaki bir kerpiç örneğinde tanımlanan ikincil sferülitlerdir (Şek. 6).

\section{Ölçülebilir Mikro Analiz Sonuçları}

\section{Kalsiyum Karbonat (CaCO3)}

Yanmış malzemeler, 1sı etkisiyle form, şekil, renk ve parçacık boyu bakımından dönüşür. Örneğin karbonat $600^{\circ} \mathrm{C}$ 'de yandı̆̆ 1 zaman yok olur ve kalsimetre ölçümlerinde düşük sonuçlar verir ya da yanmanın etkisiyle parçacık boyları orijinal boy ve renklerini kaybederler. Bu nedenle 9. binyıl ortasına tarihlenen saz örgü tekniğiyle yapılarak üzeri çamurla sıvanan ve sonrasında yangın geçirerek çökmüş olan yapılardan elde edilen kalsimetre, yanı sıra karbon ve azot analiz sonuçları değerlendirme dışında bırakılmıştır. Nitekim bu yapıların 
kerpiçlerinde yüksek oranda $\mathrm{CaCO}_{3}$ ihtiva eden kül, kömürleşmiş bitki kalıntıları yoğun olarak bulunmasına karşın yapı malzemesindeki $\mathrm{CaCO}_{3}$ oranı oldukça düşük $(<\% 2)$ çıkmıştır.

Kalsimetre sonuçları Aşıklı' daki kerpiç ve harçların < \%1 ve \%20 aralığında $\mathrm{CaCO}_{3}$ ihtiva ettiğini göstermektedir. Kerpiçlerin \%41'inin, harçların \%43'ünün $\mathrm{CaCO}_{3}$ miktarı \%5'den düşüktür. Kerpiçlerin \%29'u, harçların \%26's1 \%1'den az $\mathrm{CaCO}_{3}$ içermektedir. \%510 skalasındaki örneklerin \%20'si kerpiç, \%20'si harçtan oluşmaktadır. \%10'nun üzerinde $\mathrm{CaCO}_{3}$ ihtiva eden örnekler hem kerpiç hem de harçlarda \%10'nun, \%15'in üzerinde $\mathrm{CaCO}_{3}$ içerenler ise \%2'nin altındadır (Şek. 7).

Kalsimetre sonuçlarının tabakalara göre dağılımı 9. binyıl tabakalarından alınan örneklerin \%30'nun \%10'dan fazla $\mathrm{CaCO}_{3}$ içerdiğini, diğerlerinin ise \%8 oranında olduğunu ortaya koyar. 8. binyılın ilk yarısına gelindiğinde bu oran \%10'nun, ikinci yarısında ise hem konut alanında hem de özel amaçlı yapılar alanındaki binalarda olmak üzere \%2'nin altına düşmektedir (Şek. 7).

\section{Karbon (C) ve Azot (N)}

Aşıklı'daki kerpiç ve harçların içerdiği karbon yüzdesi \%0-3.5 aralığındadır. Kerpiç örneklerinin \%66's1 \%1'in altında, \%27'si \%1-2 arasında, \%6'sı \%2'den fazla; harç örneklerinin ise \%69'u \%1'in altında, \%25'i \%1-2 arasında, \%7'si \%2'den fazla karbon içermektedir. Diyakronik olarak incelendiğinde 9. binyılın ikinci yarısı ve $2 \mathrm{GHIJ}$ evrelerinde kerpiç örneklerinin \%75, harç örneklerinin \%95'nin karbon yüzdesi \%2'nin üzerindedir, bu oran sonraki yapı evrelerinde kerpiçlerin $\% 25$, harçların $\% 5$ 'inde $\% 1$ 'in altına düşmüştür.

Aşıklı'daki kerpiç ve harçlar \%0.02-0.2 aralığında azot ihtiva etmektedir. Kerpiç örneklerinin \%87'si \%0.02-0.06 aralığında, \%10’u \%0.06-1 aralığında, \%2'si \%0.1'den fazla; harç örneklerinin ise \%86'sı \%0.02-0.06 aralığında, \%10’u \%0.06-\%0.1 aralığında, $\% 6$ 's1 \%0.1'den fazla azot içermektedir. Kronolojik olarak bakıldığında 9. binyılın ikinci yarısında kerpiçlerde azot \%0.04'ün altında iken 8. binyılın ikinci yarısında (2GHIJ evreleri) tümü \%0.04'ün üzerine çıkar. Sonraki yapı evrelerinde tekrar düşüş gözlemlenir $(<\% 0.04)$. Harçlarda da kerpiçlerdeki ile aynı zaman dilimi ve yapı evrelerinde (2GHIJ) azot yüzdesinin görece yüksek (\%90’1\%0.2 N) olduğu saptanmıştır (Şek. 8).

\section{Tartışma}

Aşıklı Höyük’teki kerpiç ve harçlar üzerinde gerçekleştirilen ince kesit analizleri ile 9. binyılın ikinci yarısından 8. binyılın ilk çeyreğine dek kerpiçlerde, daha yoğun olarak, harçlarda hayvan dışkısı tespit edilmiştir. Dışkı sferülitleri gözenekler içerisinde ya da fitolitler ve humuslaşmış organik malzemelerle karışık halde bulunmaktadır. Hayvan dışkısı üzerine gerçekleştirilen deneysel mikromorfoloji çalışmaları bu kompozisyona dair açıklayıcı bilgiler 
sunar (S. Gur-Arieh ile özel görüşme, 2020). Söz konusu çalışma hayvan dışkısının kerpiç toprağı ile karıştırılırken dışkı sferülitlerinin organik malzemeye yapıştığını göstermektedir. Bu bilgi Aşıklı'da hayvan dışkısı ihtiva eden yapı malzemelerindeki sferülitlerin neden gözenekler, fitolitler ve organik malzemelerin çevresinde konumlandığını açıklamaktadır.

Kerpiç ve harçlardaki kalsiyum karbonat yüzdesi zamanla azalarak \%2'nin altına düşmüştür. Her iki örnek grubunun $\mathrm{pH}$ değeri ise tüm tabaka ve evrelerde 7,5-10,5 aralığında olup örneklerin tamamına yakını orta ve şiddetli alkali özelliktedir. Alkali topraklar dolomit, volkanik kayaçlar ve karbonat ihtiva eder. Asit, kalsiyum karbonat ile reaksiyona girdiğinden pH derecesi artar, bu nedenle kalsiyum karbonat ve $\mathrm{pH}$ değerleri arasında doğru orantılı bir korelasyon olması beklenir (Bohn, McNeal ve O’Connor, 2001, s. 197-198). Buradan çıkarımla Aşıklı'daki örnekler ikili korelasyon testleri ile sorgulanmış, 8. binyılın ikinci yarısına tarihlenen kerpiç ve harçlarda $\mathrm{pH}$ ve $\mathrm{CaCO}_{3}$ korelasyonunun düşük olduğu gözlemlenmiştir (Şek. 9 ve Şek. 10). Yapılan ince kesit analizlerinin de doğruladığı üzere pH değerlerinin son evrelerde artmasına sebep olan dolomit ve bazik kökenli volkanik kayaçlardır. 9. binyıl tabakalarında hayvan dışkısı içermediği tespit edilen örneklerde ise kalsiyum karbonat yüzdesi yüksektir $(>\% 8)$. Bu göstergeler birlikte değerlendirildiğinde 9. binyılda kalsiyum karbonatın dolomit ve bazik kökenli volkanik kayaçlar ya da hayvan dışkısı değil, kül ve kireç kaynaklı olduğu anlaşılmaktadır.

Azot (N) modern hayvan dışkısında yoğun olarak bulunan (Bohn ve ark., 2001, s. 65) ancak arkeolojik dışkıda tespit edilmesi tartışmalı olan (Evershed ve ark., 1997; Shahack-Gross, 2011) bir elementtir. Bu durumu Aşıklı yapı malzemeleri üzerinden sınamak için element analizleriyle ölçülen azot yüzdesi ile ince kesit analizleriyle içerisinde hayvan dışkısı olduğu tanımlanan kerpiç ve harçlar birbirleriyle karşılaştırılmıştır. Karşılaştırmada iki veri grubu arasında (azothayvan dışkısı içerenler; azot-hayvan dışkısı içermeyenler) anlamlı bir ilişki olup olmadığını belirleyebilmek amacıyla hipotez testi (T-testi) uygulanmıştır. Yapılan testler hayvan dışkısı içeren harçlardaki azot yüzdesi ile hayvan dışkısı içermeyen harçlardaki azot oranı arasında korelasyon olduğunu ortaya koymaktadır (Şek. 11). Hayvan dışkısı olan harçlarda azot oranı da yüksektir. Öte yandan kerpiç örneklerinde bu korelasyona rastlanmaz. Hayvan dışkısı içeren ve içermeyen kerpiçlerdeki azot yüzdesi birbirine yakın değerler vermektedir (Şek. 12). Bu sonuç temel bir soruyu beraberinde getirir. Kerpiç ve harçlar arasındaki söz konusu farklılığın nedeni nedir?

Olasılıklardan biri kerpiç toprağının hazırlığı sırasında azotun çözünmüş olmasıdır. Kerpiç karılırken çok fazla su kullanılmışsa kerpiç toprağındaki bazı azot kürelerinin çözünerek dağılmış olması mümkündür. Çözünen azot küreleri element analizi sonuçlarını etkilemiş olabilir. Nitekim ince kesit analizleri kerpiçlerdeki katkı malzemelerinin iyi oranlanmış ve agregaların seyrek, küçük boyutta $(<320 \mu \mathrm{m})$ ve az çeşitlilikte olduğunu dolayısıyla kerpiçlerin harçlara göre daha uzun süre ve fazla su kullanılarak karıldığını göstermektedir (Uzdurum, 2019, s. 346). 
Bir diğer olasılık hayvan dışkısının kerpiç ve harçtaki yoğunluk farkı ile ilişkilidir. İnce kesit analizleri gerek 9. binyıl oval planlı yapılar (üç yap1) gerekse 8 . binyılın ilk çeyreğine tarihlenen dörtgen binalara ait (altı bina) kerpiçlerde dışkı sferülitlerinin az miktarda olduğunu ortaya koyar. Harçlarda ise durum tam tersidir. Bina harçlarının tamamına yakını hayvan dışkısı içeriyor olmakla birlikte bu miktar 8. binyılın ilk çeyreğinde artış göstermiştir. Bu bağlamda kerpiçlerdeki hayvan dışkısının düşük miktarda olması korelasyonu önemli ölçüde etkileyen bir parametre olarak karşımıza çıkmaktadır. Son olarak azotun hayvan dışkısı dışında henüz saptayamadığımız başka bir kaynağı olduğu da öneriler arasındadır.

Topraklarda karbon (C), organik ve inorganik olmak üzere iki şekilde bulunmaktadır. Organik karbonun büyük bir bölümü organik maddeye işaret ederken, inorganik karbon genellikle kalsit ve dolomit topraklarda olduğu gibi karbonat mineralleri içerisinde yer almaktadır (Kacar, 2012, s. 92). Toplam organik karbon (TOC) hesaplaması ${ }^{7}$ ile ulaşılan organik karbon yüzdesi, topraktaki organik maddenin yüzde olarak miktarını vermektedir. $\mathrm{Bu}$ nedenle azot ve hayvan dişkısı üzerinde yapılan hipotez testi organik karbon (TOC), karbon (C) ve hayvan dışkısı üzerinde de uygulanmıştır. Öncelikle hayvan dışkısı içeren harçlardaki organik karbon miktarı ile hayvan dışkısı içermeyen harçlardaki organik karbon miktarı arasındaki korelasyon, ardından hayvan dışkısı içeren harçlardaki karbon miktarı ile hayvan dışkısı içermeyen harçlardaki karbon miktarı arasındaki korelasyon test edilmiştir. Yapılan testler hayvan dışkısı içeren harçlardaki $\% \mathrm{C}_{\text {org }}$ ve $\% \mathrm{C}$ miktarının hayvan dışkısı içermeyenlerden daha yüksek olduğunu göstermektedir (Şek. 13). Öte yandan aynı sorgulama kerpiçler için yapıldığında gerek $\% \mathrm{C}_{\text {org }}$ gerekse $\% \mathrm{C}$ miktarının hayvan dışkısı içeren ve içermeyen örnekler arasında belirgin bir farklılığa işaret etmediği görülür (Şek. 14).

Hipotez testlerinde saptanan harçlarla kerpiçler arasındaki söz konusu farklılık organik karbonun yalnızca hayvan dışkısı ile ilgili olmadığına işaret etmektedir. Öyleyse bahsi geçen binaların kerpiçlerinde olmayan ya da az bulunan, harçlarında ise organik karbon oranını $\% 0.5$ 'in üzerine çıkartan mikro kalıntı nedir? Bu soru doğrultusunda ve organik karbonun hayvan dışkısı haricinde farklı organik malzemelerde de bulunduğu bilgisiyle bu kez antropojenik malzeme oranı ile organik karbon arasındaki ilişkiye odaklı hipotez testleri yapılmıştır. Sonuçlar antropojenik malzemenin yoğun olduğu harç örneklerinde organik karbon ve karbon oranının da yüksek olduğunu göstermiştir. Azot ile az ya da yoğun miktarda antropojenik malzeme içeren yapı malzemeleri arasında ise farklılığın belirgin olmadığı anlaşılmaktadır (Şek. 15). Dolayısıyla yapılan testler organik karbonun hayvan dışkısının yanı sıra ince kesit analizleriyle tanımlanan (Uzdurum, 2019, s. 218) çitlembik kırıkları, kabuk, kül, hayvan kemiği, bitki kalıntıları gibi antropojenik malzemelerin varlığına işaret ettiğini doğrulamaktadır. Bu sonuç kerpiç ve harçlardaki organik karbon miktarının neden zaman içerisinde azaldığı sorusuna da 1şık tutar. Nitekim hayvan dışkısı başta olmak üzere

$7 \quad \mathrm{TOC}=\% \mathrm{C}-(\% \mathrm{CaCO} 3 / 8.33)$ 
diğer pek çok antropojenik malzeme (bitki kalıntıları hariç) 8. binyıl konutlarının kerpiç ve harçlarında ender olarak karşımıza çıkmaktadır.

İnce kesit analizlerinin işaret ettiği üzere hayvan dışkısı 8. binyılın ikinci yarısından itibaren katkı malzemesi olarak kullanılmamıştır. Ölçülebilir analizlerle incelenen örneklerde organik karbonun yanı sıra azot miktarının ve kalsiyum karbonat yüzdesinin de zaman içerisinde azalmış olması, ayrıca azotun hayvan dışkısının en yoğun kullanıldığı yapı evrelerindeki harçlarda baskın olması bu olasılığı kuvvetlendirir.

Analitik sonuçların mekansal karşılaştırması yapıldığında ise özel amaçlı yapılar alanındaki kerpiçlerde $\mathrm{C}_{\text {org }}$ ve $\mathrm{CaCO}_{3}$ miktarının konut alanındakilerden daha yüksek olduğu dolayısıyla özel alandaki binalar için üretilen kerpiçlerde daha fazla antropojenik malzeme kullanıldığı önerilebilir. Yine bu alandaki kerpiçlerde saptanan azot yoğunluğu söz konusu antropojenik malzemelerden birinin hayvan dışkısı olduğuna işaret etmektedir (Şek. 16). Mekansal karşılaştırma harçlar üzerinden yapıldığında özel alandakilerin $\mathrm{N}$ ve $\mathrm{CaCO}_{3}$ bakımından yine daha zengin bir tablo çizdiği görülmektedir. Buna karşın kerpiçlerden farklı olarak harçlarda $\mathrm{C}_{\text {org }}$ bağlamında konut alanı ve özel amaçlı yapılar alanı arasında belirgin bir farklılık bulunmamaktadır (\%0.02-0.41) (Şek. 17).

Konutlar ile karşılaştırıldığgnda azot yüzdesinin özel amaçlı yapılar alanında daha yüksek olması özel alandaki binaların yapı malzemelerine hayvan dışkısı katıldığını düşündürmesine karşın özel alanda yeterli sayıda kerpiç ve harç üzerinde ince kesit analizi yapılamamış olması bu çıkarımın sınanmasını gerektirmektedir. $\mathrm{Bu}$ amaçla ince kesit analizleriyle tanımlanan hayvan dışkısı içermeyen (6 örnek), hayvan dışkısı içeren (3 örnek) ve hem hayvan dışkısı hem de antropojenik malzeme içeren (1 örnek) kerpiç ve harçlar üzerinde Susan Mentzer tarafından mikro-XRF ile fosfor miktarı ölçülmüştür. Sonuçlar hayvan dışkısı içeren yapı malzemelerinde fosfor oranının da yüksek olduğunu ortaya koyması bakımından önerimizi destekler. Öte yandan yerleşmede hayvan tutulan alanların düzlemlerinden alınan hayvan dışkıları referans olarak kullanılarak hayvan dışkısı içermeyen (16 örnek), hayvan dışkısı ve antropojenik malzeme içeren (13 örnek) ve hayvan dışkısı içeren ancak antropojenik malzeme içermeyen (6 örnek) örnekler üzerinde $\mathrm{N}$ (azot), P (fosfor), K (potasyum) testi gerçekleştirildiğinde fosfor ve azot miktarı ile hayvan dışkısı arasında korelasyon bulunmadığı anlaşılmıştır (S. Mentzer ile özel görüşme, 2020). Böylelikle yerleşmede özel alanda bulunan binaların kerpiç ve harçlarından mikromorfoloji örneklemesi yapılmasının gerekliliği tekrar önem kazanmakla birlikte ince kesit analizlerinin arkeolojik yerleşmelerdeki dışk1 kalıntılarının tespit edilmesine sunduğu katkı yeniden doğrulanmaktadır.

\section{Sonuç}

Aşıklı Höyük’te gerçekleştirmiş olduğumuz gözlemlenebilir ve ölçülebilir mikro analizler kerpiç ve harçlarda hayvan dışkısının tespit edilmesine yönelik bazı analitik 
belirleyiciler olduğunu ortaya koymaktadır. Kerpiç ve harçlar üzerinde mikromorfoloji, kalsiyum karbonat, karbon ve azot element analizleri kullanılarak ulaşılan sonuçlar arkeolojik dışk1 tanımlamalarında birbirinden farklı sorgulamalar yapmaya imkan sağlayan mikrogöstergelere dayalıdır. Bu mikro-göstergeler dışkı sferülitleri ve kimyasal elementlerdir. Sferülitler, dışkının doğrudan kanıtıdır ve bu nedenle çalışmamızda araştırılması gereken ilk mikro veri grubunu oluşturmuştur.

Aşıklı Höyük’te ince kesit analizleriyle mikroskop altında tanımlanan dışkı sferülitleri ve bunların mikro-bağlamı, harçlarda hayvan dışkısının katkı malzemesi olarak yoğun bir şekilde kullanıldığını ortaya koymuştur. Yoğun dışkı kullanımı, 9. binyılın ikinci yarısına yani yerleşmenin erken zamanlarına denk gelir. Bu zaman dilimi Aşıklı sakinlerinin sınırlı sayıda koyun/keçiyi evlerin hemen yanı başındaki yapılar içerisinde kontrol altında tutmaya başladığı bir dönemdir. Hayvan tutulan alanların genişletildiği 8. binyılın başında hayvan dışkısı kullanımı harçlarda kısmen artmıştır. Hayvanların kontrol edildiği alanların yerleşmenin dışına taşındığı ve yerleşmenin iki ana işlevsel alana ayrıldığı 8. binyılın ikinci yarısında ise kerpiç ve harçlarda dışkı sferüliti tespit edilmemiştir.

Dışkı sferülitleri her ne kadar hayvan dışkısının varlığına işaret eden en güvenilir mikrogöstergeler olsa da sferülitlerin görünmemesi örnekler içerisinde hayvan dışkısı bulunmadığını kanıtlamaz. Özellikle toprağın $\mathrm{pH}$ derecesi sferülitlerin korunmalarını engelleyen ana faktörlerden biri olarak bilinir. Bu değer 7'nin altındaysa sferülitler çözündükleri için mikroskop altında tanımlanamazlar (Canti, 1999). Aşıklı' da yapı malzemelerindeki pH değeri $>$ 7,5 olduğu için sferülitlerin korunmasını engelleyecek bir durum bulunmaz. Öte yandan azot ve ince kesit analizlerinden elde edilen sonuçlarla yapılan korelasyon testleri 9. binyıl kerpiçlerinde toprağın uzun süre, çok miktarda su ile karılmasının sferülitlerin çözünmesine neden olmuş olabileceğine işaret etmektedir. Bu bağlamda ulaştığımız sonuçlardan biri söz konusu analizlerin kombinasyonu ile birbirinden farklı ortam ve süreçlerde korunabilen ya da çözünen arkeolojik hayvan dışkılarının ayırt edilebileceğidir.

8. binyılın ikinci yarısında gerek kerpiç gerekse harçlarda organik karbon, karbon, azot ve kalsiyum karbonat miktarının hızla düşmesi hayvan dışkısının azaldığını/ortadan kalktığını ortaya koyan ince kesit sonuçlarıyla güçlü bir uyum içerisindedir. Diğer yandan kerpiçlerdeki organik karbon ve azot miktarının özel amaçlı yapılar alanında kısmen daha yüksek olması, ayrıca bu alandaki binalardan ince kesit analizi yapılmış bir örnekte dışkı sferülitlerine rastlanması özel amaçlı yapılar alanındaki binaların yapı malzemelerine hayvan dışkısı katıldığına işaret eder. İncelenen örneğin tekil olması yanı sıra organik karbon ve azot yüzdesinin iki alan arasında belirgin bir fark ortaya koymaması özel alandaki kerpiç ve harçlar üzerinde ileride yapılacak ince kesit analizleriyle bu sonucun sınanmasını gerektirmektedir. Ancak yine de bağlayıcı olarak dışkının konut alanlarında tamamıyla ortadan kalkarken özel amaçlı yapılar alanında kullanılıyor olma olasılığı düşündürücüdür. $\mathrm{Bu}$ durum 9 . 
binyıl kerpiç ve harç tariflerinin özel yapılarda sürdürülmeye devam ediyor olması ve özel yapılarda konutlardan farklı kerpiç üretim tekniklerinin uygulanması ile açıklanabileceği gibi hayvan dışkısının Aşıklı sakinleri için sembolik bir anlamının olabileceği ihtimalini de düşündürmektedir. Bu alanın topluluk için farklı bir anlamı olduğu, buradaki anıtsal ölçekteki binalar ve faaliyetlerle bilinmektedir (Özbaşaran ve ark., 2018). Hemen her yapı özenli bir şekilde inşa edilmiş, kalıcılık ve uzun ömürlülük esas alınmıştır. Kerpiç, bu alandaki yapılarda konutlardan farklı olarak döşeme, taban temeli, istinat duvarı gibi farklı amaçlarla da kullanılmıştır (Duru, 2005). Tüm bu nedenlerle buradan alınacak örneklerin çoğaltılması, topluluğun iskan stratejisini daha iyi anlamak adına önemlidir.

Mikromorfolojinin en temel kısıtlaması örnek boyutlarının küçük, yapı duvarlarının uzunluğu ve yüksekliği düşünüldüğünde örnek sayısının az olmasıdır. Bu nedenle ince kesit çalışmalarından elde edilen verinin ölçülebilir mikro analizlerle sınanması önem kazanır. Bu bağlamda ulaştığımız sonuçlardan bir diğeri azot element analizlerinin ince kesit sonuçlarını büyük oranda doğruladığıdır. Böylelikle hem diyakronik olarak hem de konut alanındaki çok sayıda, çeşitlilikte ve ince kesit örneklemesi yapılamayan kerpiç ve harçlardaki hayvan dışkısının element analizleriyle takip edilmesi mümkün hale gelmiştir. Element analizleri bir yanıyla ince kesit hazırlığının teknik gerekçelerle Türkiye'de yapılamıyor olması, yurt dışındaki laboratuvarlarda yapıldığında ise yüksek maliyet gerektirmesi ve bürokratik zorluklarla karşılaşılması nedeniyle avantaj sağlamaktadır. Öte yandan arkeolojik mikromorfolojinin dışkı sferülitlerinin tanımlanmasında en güvenilir yöntemlerden biri ve element analizlerini tamamlayıcı olduğu da gözden kaçırılmamalıdır. Bu anlamda hayvan dışkısının aynı sorunsal çerçevesinde çok çeşitli mikro analizlerin bir araya getirildiği çok-göstergeli yaklaşımla incelenmesinin önemi ön plana çıkar. Aşıklı Höyük’teki yapı malzemeleri üzerine gerçekleştirmiş olduğumuz bu çalışmanın ilerideki yıllarda yapılması planlanan fitolit ve azot izotop analizlerini de yönlendireceği ve tamamlayacağı kuşkusuzdur. Böylelikle arkeolojik hayvan dışkısının kullanımına dair bildiklerimizin yelpazesini daha da genişletmek mümkün olabilecektir. 
Teşekkür/Acknowledgement: Tübingen Üniversitesi Toprak Bilimleri ve Jeoekoloji Laboratuvarı'nda kimyasal analizlerin yapılmasına imkan veren Dr. Peter Kuhn'a, ince kesit hazırlığında emeği geçen Panagiotis Kritikakis'e, mikroskop çalışmalarının Tübingen Üniversitesi Jeoarkeoloji Departmanı'nda gerçekleştirilmesini sağlayan Dr. Susan M. Mentzer ve Prof. Christopher Miller'e ve bu çalışmaya ilişkin yönlendirme ve desteklerinden ötürü başta Prof. Mihriban Özbaşaran'a ve Aşıklı Höyük kazı ekibine teşekkür ederiz. TC Kültür ve Turizm Bakanlığı ile Kültür Varlıkları ve Müzeler Genel Müdürlüğü kazı çalışmaları ve örneklerin yurtdışına gönderilmesinde gereken tüm izinleri sağlamıştır.

Hakem Değerlendirmesi: Dış bağımsız.

Çıkar Çatışması: Yazarlar çıkar çatışması bildirmemiştir.

Finansal Destek: Bu çalışmada gerçekleştirilen tüm analizler Türk-Amerikan İlmi Araştırmalar Derneği (ARIT)-Machteld J. Mellink yurtdışı doktora bursu (Melis Uzdurum), Koç Üniversitesi-Anadolu Medeniyetleri Araştırma Merkezi (ANAMED) doktora bursu (Melis Uzdurum), National Science Foundation (BCS-1354138, BCS-0912148, Prof. Mary C. Stiner), DAAD (Dr. Susan M. Mentzer) ve Ludwig Maximilian University (Prof. Joris Peters) tarafindan desteklenmiştir.

Peer-review: Externally peer-reviewed.

Conflict of Interest: The author has no conflict of interest to declare.

Grant Support: These analyses were supported by the American Research Institute in Turkey (ARIT), and Koç University Research Center for Anatolian Civilizations (RCAC) research grants to Melis Uzdurum, National Science Foundation Grants (BCS-09121418 and BCS-09121418) to Prof. Mary C. Stiner, German Academic Exchange Service (DAAD) research grant to Dr. Susan M. Mentzer, and Ludwig Maximilian University-İstanbul University Funding to Prof. Joris Peters (6647).

\section{Kaynakça/References}

Abell, J., Quade, J., Duru, G., Mentzer, SM., Stiner, MC., Uzdurum, M., Özbaşaran, M. (2019). Urine salts elucidate Early Neolithic animal management at Aşıklı Höyük, Turkey. Science Advance, 5 (4), 1-10. https://doi.org/10.1126/sciadv.aaw0038

Berna, F. (2017). Geo-ethnoarchaeology study of the traditional Tswana dung floor from the Moffat mission church, Kuruman, north Cape Province, South Africa. Archaeological and Anthropological Science, 1-9. https://doi.org/10.1007/s12520-017-0470-0/

Bogaard, A., Heaton, THE., Poulton, PR., Merbach, I. (2007). The impact of manuring on nitrogen isotope ratios in cereals: Archaeological implications for reconstruction of diet and crop management practices. Journal of Archaeological Science, 34, 335-343. https://doi.org/10.1016/j.jas.2006.04.009

Bohn, HL., McNeal, BL., O’Connor, GA. (2001). Soil Chemistry. Third edition, John Wiley \&Sons, INC.

Boivin, N. (2000). Life rhythms and floor sequences: excavating time in rural Rajasthan and Neolithic Catalhoyuk. World Archaeology, 31, 367-388. https://doi.org/10.1080/00438240009696927

Bourguet, C. (2015). Analyse anthracologique du site néolithique d'Aşıklı Höyük (Turquie): résultats préliminaires. (Master Dissertation). Museum National d'Histoire Naturelle, UMR 7209 Archéozoologie et Archéobotanique, Paris.

Brochier, J.E., Villa, P., Giacomarra, M., Tagliacozzo, A. (1992). Shepherds and sediments: geoethnoarchaeology of pastoral sites. Journal of Anthropological Archaeology, 11, 47-102. https://doi. org/10.1016/0278-4165(92)90010-9

Buitenhuis, H., Peters, J., Pöllath, N., Stiner, MC., Munro, ND., Sarıtaş, Ö. (2018). The Faunal Remains from Levels 3 and 2 of Aşı1klı Höyük: Evidence for Emerging Management Practices. M. Özbaşaran, G. Duru, M. Stiner (Eds.), The Early Settlement at Aşıkl Höyük- Essays in Honor of Ufuk Esin. İstanbul: Ege Yayınları, 281-323.

Canti, MG. (1997). An investigation of microscopic calcareous spherulites from herbivore dung. Journal of Archaeological Science, 24, 219-231. https://doi.org/10.1006/jasc.1996.0105 
Canti, MG. (1998). The micromorphological identification of faecal spherulites from archaeological and modern materials. Journal of Archaeological Science, 25, 435-444. https://doi.org/10.1006/jasc.1997.0210

Canti, MG. (1999). The production and preservation of faecal spherulites: animals, environment and taphonomy. Journal of Archaeological Science, 26, 251-258. https://doi.org/10.1006/jasc.1998.0322

Canti, MG., Brochier, JE. (2017). Faecal Spherulites. C. Nicosia, G. Stoops (Eds.), Archaeological Soil and Sediment Micromorphology, Wiley, 51-55.

Courty, MA., Goldberg, P., Macphail, RI. (1989). Soils and micromorphology in Archaeology. Cambridge: Cambridge University Press.

Courty, MA., Macphail, RI., Wattez, J. (1991). Soil micromorphological indicators of pastoralism; with special reference to Arene Candide, Finale Ligure, Italy. Rivista di Studi Liguri, LVII, 127-150.

Crowther, J. (2002). The experimental earthwork at Wareham, Dorset after 33 years: retention and leaching of phosphate released in the decomposition of buried bone. Journal of Archaeological Science, 29, 405-411. https://doi.org/10.1006/jasc.2002.0728

Duru, G. (2005). Yakındoğu Neolitiğinde Orta Anadolu Bölgesi Neolitik Dönem Mimarlı̆̆ının Yeri. (Yüksek Lisans Tezi). İstanbul Teknik Üniversitesi Sosyal Bilimler Enstitüsü, İstanbul.

Duru, G. (2013). Tarihöncesinde Insan-Mekan, Topluluk-Yerleşme İlişsisi: MÖ 9. Bin Sonu 7. Bin Başı, Aşıklı ve Akarçay Tepe. (Doktora Tezi). İstanbul Üniversitesi Sosyal Bilimler Enstitüsü, İstanbul.

Eksambekar, SP., Kajale, MD. (2007). Phytolith analysis for understanding formation processes at Neolithic Budhial, district Gulbarga, South India. K. Paddayya, R. Jhaldiyal, GD. Sushama (Eds.), Formation processes and Indian archaeology. Pune: Deccan College Post Graduate and Research Institute, 267-277.

Esin, U. (1996). On bin yıl Öncesinde Aşıklı: Anadolu'da bir yerleşim modeli (Aşıklı, ten thousand years ago: a habitation model from central Anatolia), Tarihten Günümüze Anadolu'da Konut ve Yerleşme, 31-42.

Esin, U., Harmankaya, S. (2007). Aşıklı Höyük. M. Özdoğan, N. Başgelen (Eds.), Türkiye 'de Neolitik Dönem. İstanbul: Arkeoloji ve Sanat Yayınları, 255-272.

Evershed, RP., Bethell, PH., Reynolds, PJ., Walsh, NJ. (1997). 5[ $\beta]$-Stigmastanol and related 5[ $\beta]$-Stanols as biomarkers of manuring: analysis of modern experimental material and assessment of the archaeological potential. Journal of Archaeological Science, 24, 485-495.

Friesem, DE., Karkanas, P., Tsartsidou, G., Shahack-Gross, R., (2014). Sedimentary processes involved in mud brick degradation in temperate environments: a micromorphological approach in an ethnoarchaeological context in northern Greece. Journal of Archaeological Science, 41, 556-567. https://doi.org/10.1016/j. jas.2013.09.017

Fuks, D., Dunseth, ZC. (2021). Dung in the dumps: what we can learn from multi-proxy studies of archaeological dung pellets. Vegetation History and Archaeobotany, 30, 137-153. https://doi.org/10.1007/ s00334-020-00806-x

Goodman-Elgar, M. (2008). The devolution of mudbrick: ethnoarchaeology of abandoned earthen dwellings in the Bolivian Andes. Journal of Archaeological Sciences, 35, 3057-3071. https://doi.org/10.1016/j. jas.2008.05.015

Goren, Y. (1999). On determining use of pastoral cave sites: a critical assessment of spherulites in archaeology. Journal of the Israel Prehistoric Society, 29, 23-128.

Gur-Arieh, S., Madella, M., Lavi, N., Friesem, D.E. (2019). Potentials and limitations for the identification of outdoor dung plasters in humid tropical environment: a geo-ethnoarchaeological case study from South 
India. Archaeological and Anthropological Sciences, 11, 2683-2698. https://doi.org/10.1007/s12520018-0682-y

Gur-Arieh, S., Mintz, E., Boaretto, E., Shahack-Gross, R. (2013). An Ethnoarchaeological Study of Cooking Installations in Rural Uzbekistan: Development of a New Method for Identification of Fuel Sources, Journal of Archaeological Science, 40 (12), 4331-4347. https://doi.org/10.1016/j.jas.2013.06.001

Gur-Arieh S., Shahack-Gross R., Maeir, AM., Lehmann, G., Hitchcock, LA., Boaretto, E. (2014). The taphonomy and preservation of wood and dung ashes found in archaeological cooking installations: case studies from Iron Age Israel. Journal of Archaeological Science 46, 50-67. https://doi.org/10.1016/j.jas.2014.03.011

Horwitz, LK., Goldberg, P. (1989). A Study of Pleistocene and Holocene hyaena coprolites. Journal of Archaeological Science, 16, 71-94. https://doi.org/10.1016/0305-4403(89)90057-5

Kacar, B. (2012). Toprak Analizleri. 3. baskı, Nobel Akademik Yayıncılık.

Kalkan, F., Özbal, R. (2018). Multi-element Characterization of Floors at Aşıklı Höyük: Contributing to the Identification of Activities and Activity Areas. M. Özbaşaran, G. Duru, M. Stiner (Eds.), The Early Settlement at Aşıllı Höyük- Essays in Honor of Ufuk Esin. İstanbul: Ege Yayınları, 129-145.

Kalkan, F., Özbaşaran, M., Özbal, R. (2020). Tarihöncesi Mekanlarda Gerçekleştirilen Faaliyetlerin Tanımlanmasında Toprak Kimyası Analizinin Rolü: Aşı1ılı Höyük Örneği. Süleyman Demirel Üniversitesi Fen-Edebiyat Fakültesi Sosyal Bilimler Dergisi, 50, 240-254.

Karkanas, P. (2006). Late Neolithic household activities in marginal areas: the micromorphological evidence from the Kouveleiki caves, Peloponnese, Greece. Journal of Archaeological Science, 33, 1628-1641. https://doi.org/10.1016/j.jas.2006.02.017

Kayacan, N., Algül, Ç. (2019). A Knapping Area in an $8^{\text {th }}$ millennium BC Building at Aşıklı Höyük, East-Central Anatolia, L. Astruc, C. McCartney, F. Briois, V. Kassianidou (Eds.), Near Eastern Lithic Technologies on the Move. Interactions and Contexts in Neolithic Traditions, $8^{\text {th }}$ International Conferences on PPN Chipped and Ground Stone Industries of the Near East, November 23 $3^{\text {rd }}-27^{\text {th }} 2016$, Astrom Editions, Nicosia, 227-234.

Lancelotti, C., Madella, M. (2012). The "invisible" product: developing markers for identifying dung in archaeological contexts. Journal of Archaeological Science, 39, 953-963. https://doi.org/10.1016/j. jas.2011.11.007

Love, S. (2012). The geoarchaeology of mudbricks in architecture: a methodological study from Çatalhöyük, Turkey. Geoarchaeology, 27, 140-156. https://doi.org/10.1002/gea.21401

Macphail, RI., Cruise, GM., Allen, MJ., Linderholm, J., Reynolds, P. (2004). Archaeological soil and pollen analysis of experimental floor deposits; with special reference to Butser ancient farm, Hampshire, UK. Journal of Archaeological Science, 31, 175-191.

Mbae, NB. (1990). The ethnoarchaeology of Maasai settlements and refuse disposal patterns in the Lemek area. P. Robertshaw (Ed.), Early pastoralists of south-western Kenya, British Institute in Eastern Africa Memoir. Nairobi: British Institute in Eastern Africa, 279-292.

Mentzer, SM. (2018). Micromorphological Analyses of Anthropogenic Materials and Insights into Tell Formation Processes at Aşıklı Höyük, 2008-2012 Seasons. M. Özbaşaran, G. Duru, M. Stiner (Eds.), The Early Settlement at Aşılkl Höyük- Essays in Honor of Ufuk Esin. İstanbul: Ege Yayınları, 105-128.

Miller, NF. (1984). The use of dung as fuel: an ethnographic example and an archaeological application. Paléorient, 10, 71-79. 
Noei, S. (2017). Tarihöncesi Anadolu'da (MÖ 8500-3500) Yapı Malzemesi Olarak Kerpicin Arkeolojik ve Arkeometrik Değerlendirilmesi. (Doktora tezi). İstanbul Üniversitesi Sosyal Bilimler Enstitüsü, İstanbul.

Otaegui, A.A., Polo-Diaz, A., Richter, T. (2017). Dung use before animal domestication in southwest Asia: evidence from early Natufian Shubayqa 1 (northeastern Jordan). Abstract from Annual Meeting of the Society of American Archaeologist 2017, Canada: Vancouver.

Özbaşaran, M. (2011). Re-starting at Aşıklı. Anatolia Antiqua, XIX, 27-37.

Özbaşaran, M., Duru, G. (2015). The Early Sedentary Community of Cappadocia: Aşıklı Höyük. D. Beyer, O. Henry, A. Tibet, (Eds.), La Cappadoce Méridionale de la préhistoire a la période byzantine. Institut Français d'Etudes Anatoliennes Georges-Dumézil, 8-9 Novembre, 2012, İstanbul, 43-51.

Özbaşaran, M., Duru, G., Uzdurum, M. (2018). Architecture of the Early Settlement and Trends through the Cultural Sequence. M. Özbaşaran, G. Duru, M. Stiner (Eds.), The Early Settlement at Aşıklı HöyükEssays in Honor of Ufuk Esin. İstanbul: Ege Yayınları, 57-103.

Pearson, JA., Buitenhuis, H., Hedges, REM., Martin, L., Russell, N., Twiss, K. (2007). New light on early caprine herding strategies from isotope analysis: a case study from Neolithic Anatolia. Journal of Archaeological Science, 34, 2170-2179. https://doi.org/10.1016/j.jas.2007.09.001

Piperno, DR. (2006). Phytoliths: a Comprehensive Guide for Archaeologist and Paleoecologists. Academic Press: Lanham.

Portillo, M., Albert, RM. (2011). Husbandry practices and livestock dung at the Numidian site of Althiburos (el Médéina, kef governorate, northern Tunisia): the phytolith and spherulite evidence. Journal of Archaeological Science, 38, 3224-3233. https://doi.org/10.1016/j.jas.2011.06.027

Portillo, M., Albert, RM., Henry, DO. (2009). Domestic activities and spatial distribution in Ain Abū Nukhayla (Wadi rum, southern Jordan): the use of phytoliths and spherulites studies. Quaternary International, 193, 174-183. https://doi.org/10.1016/j.quaint.2007.06.002

Portillo, M., Garcia-Suarez, A., Matthews, W. (2020). Livestock faecal indicators for animal management, penning, feddering and dung use in early agricultural built environments in the Konya Plain, Central Anatolia. Archaeological and Anthropological Sciences, 12 (40), 1-15. https://doi.org/10.1007/s12520019-00988-0

Portillo, M., Kadowaki, S., Nishiaki, Y., Albert, RM. (2014). Early Neolithic household behavior at tell Seker al-Aheimar (upper Khabur, Syria): a comparison to ethnoarchaeological study of phytoliths and dung spherulites. Journal of Archaeological Science, 42, 107-118. https://doi.org/10.1016/j.jas.2013.10.038

Quade, J., Stiner, MC., Copeland, A., Clark, AE., Özbaşaran, M. (2018). Summary of Carbon-14 Dating of the Cultural Levels of Aşıklı Project. M. Özbaşaran, G. Duru, M. Stiner (Eds.), The Early Settlement at Aşıklı Höyük- Essays in Honor of Ufuk Esin. İstanbul: Ege Yayınları, 43-56.

Schelvis, J. (1992). The identification of archaeological dung deposits on the basis of remains of predatory mites (Acari; Gamasida). Journal of Archaeological Sciences, 19, 677-682.

Schumacher, M. (2017). Biomolecular and micromorphological analyses of suspected fecal deposits at Neolithic Aşıklı Höyük, Turkey. (M.Sc. Thesis). University of Tübingen, Tübingen.

Shahack-Gross, R. (2011). Herbivorous livestock dung: formation, taphonomy, methods for identification, and archaeological significance. Journal of Archaeological Science, 38, 205-218. https://doi.org/10.1016/j. jas.2010.09.019 
Shahack-Gross, R., Albert, RM., Gilboa, A., Nagar-Hilman, O., Sharon, I., Weiner, S. (2005). Geoarchaeology in an urban context: the uses of space in a Phoenician monumental building at Tel Dor (Israel). Journal of Archaeological Science, 32, 1417-1431. https://doi.org/10.1016/j.jas.2005.04.001

Shahack-Gross, R., Marshall, F., Ryan, K., Weiner, S. (2004). Reconstruction of spatial organization in abandoned Maasai settlements: implications for site structure in the pastoral Neolithic of East Africa. Journal of Archaeological Science, 31, 1395-1411. https://doi.org/10.1016/j.jas.2004.03.003

Shillito, LM. (2017). Multivocality and multiproxy approaches to the use of space: lessons from 25 years of research at Çatalhöyük. World Archaeology, 49 (2), 237-259. https://doi.org/10.1080/00438243.2016.12 71351

Shillito, LM., Bull, ID., Matthews, W., Almond, MJ., Williams, JM., Evershed, RP. (2011). Biomolecular and micromorphological analysis of suspected faecal deposits at Neolithic Çatalhöyük, Turkey. Journal of Archaeological Science, 38 (8), 1869-1877. https://doi.org/10.1016/j.jas.2011.03.031

Simpson, IA., Dockrill, SJ., Bull, ID., Evershed, RP. (1998). Early anthropogenic soil formation at Tofts Ness, Sanday, Orkney. Journal of Archaeological Science, 25, 729-746. https://doi.org/10.1006/jasc.1997.0216

Simpson, IA., Vésteinsson, O., Adderley, WP., McGovern, TH. (2003). Fuel resource utilisation in landscapes of settlement. Journal of Archaeological Science, 30, 1401-1420. https://doi.org/10.1016/S03054403(03)00035-9

Spengler, RN III. (2019). Dung burning in the archaeobotanical record of West Asia: where are we now? Vegetation History and Archaeobotany, 28, 215-227. https://doi.org/10.1007/s00334-018-0669-8

Stiner, MC., Bailey, KS., Munro, ND., Christidou, R. (2018). Spatial and Zooarchaeological Evidence of Human-Animal Interactions in the Early PPN Settlement at Aşıklı Höyük. M. Özbaşaran, G. Duru, M. Stiner (Eds.), The Early Settlement at Aşıklı Höyük- Essays in Honor of Ufuk Esin. İstanbul: Ege Yayınlar1, 219-257.

Stiner, MC., Buitenhuis, H., Duru, G., Kuhn, SL., Mentzer, SM., Munro, ND., Pöllath, N., Quade, J., Tsartsidou, G., Özbaşaran, M. (2014). A forager-herder trade-off, from broad-spectrum hunting to sheep management at Aşılıl Höyük, Turkey. Proceedings of the National Academy of Sciences (PNAS), 111, 8404-8409. https://doi.org/10.1073/pnas.1322723111

Stoops, G. (2003). Guidelines for Analysis and Description of Soil and Regolith Thin Sections. Soil Science Society of America.

Tsartsidou, G. (2018). The Microscopic Record of Aşıklı Höyük: Phytolith Analysis of Material from the 2012-2016 Field Seasons. M. Özbaşaran, G. Duru, M. Stiner (Eds.), The Early Settlement at Aşıklı Höyük- Essays in Honor of Ufuk Esin. İstanbul: Ege Yayınları, 147-189.

Uzdurum, M. (2018). Live together around fire: Hearths and the use of space at the onset of sedentism. Aşıklı Höyük (Turkey), a case study. C. Douché, F. Pichon (Eds.), From the Caucasus to the Arabian Peninsula: Domestic Spaces in the Neolithic, Proceedings of the International Conference. Actes Du Colloque International, Routes de l'Orient, 11-49.

Uzdurum, M. (2019). MÖ 9. - 8. Bin Yıl Kerpiç Mimarisine Mikroarkeolojik Bir Yaklaşım: Aşılkl Höyük’te Kerpiç ve Harç Tarifleri. (Doktora Tezi). İstanbul Üniversitesi Sosyal Bilimler Enstitüsü, İstanbul.

Van Geel, B. (2001). Non-pollen palynomorphs. J. Smol, J. Birks J, W. Last (Eds.), Tracking environmental changes using lake sediments, 3. Terrestrial, algal and siliceous indicators. Dordrecht: Kluwer Academic Press, 99-119. 
Viklund, K., Linderholm, J., Macphail, RI. (2013). Integrated palaeoenvironmental study: micro- and macrofossil analysis and geoarchaeology (soil chemistry, magnetic susceptibility and micromorphology). LE. Gerpe (Ed.), E18-prosjektet Gulli-Langåker. Oppsummering og arkeometriske analyser, Volume Bind 3: Bergen, Fagbokforlaget, 25-83.

Wayne DW. (1990). Applied Nonparametric Statistics, Boston: PWS-Kent, 226-234.

Weiner, S. (2010). Microarchaeology. Beyond the Visible Archaeological Record. Cambridge University Press: New York.

Zapata Peña, L., Peña-Cocarro, L., Ibáñez Estévez, J.J., González Urquijo, J.E. (2003). Ethnoarchaeology in the Moroccan Jebala (Western Rif): wood and dung as fuel. K. Neumann, A. Butler, S. Kahlheber (Eds.), Food, Fuel, and Fields. Progressin African Archaeobotany. Heinrich Bart Institut, 163-175.

Zimmermann, MI., Pöllath, N., Özbaşaran, M., Peters, J. (2018). Joint health in free-ranging and confined small bovids - Implications for early stage caprine management. Journal of Archaeological Science, 92, 13-27. https://doi.org/10.1016/j.jas.2018.02.004 


\section{Şekiller}

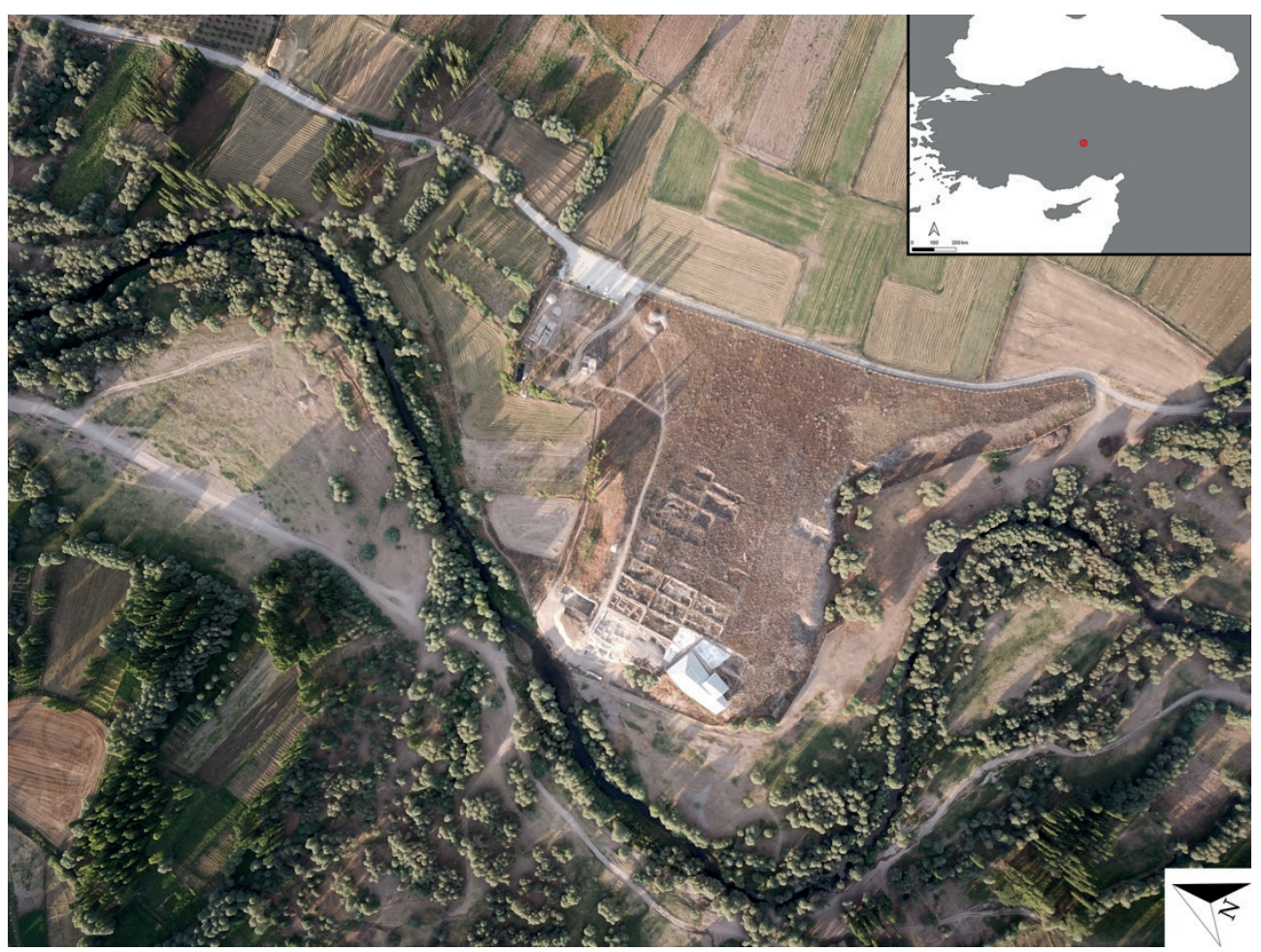

Şekil 1. Aşıklı Höyük'ün konumunu ve çevresini gösteren hava fotoğrafi (Hava fotoğrafi: Aşıklı Höyük Kazı ve Araştırma Projesi Arşivi). 


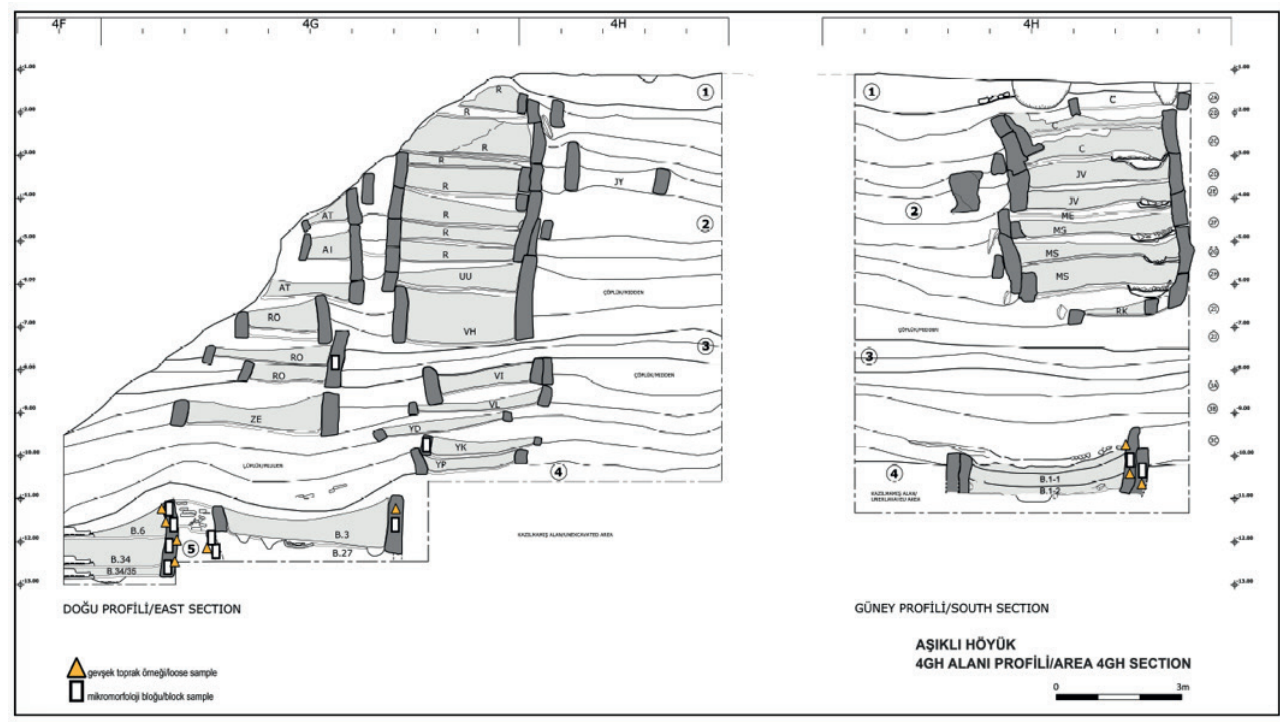

Şekil 2. 9. binyıl ortası, 4GH Alanı, gevşek ve kesilmiş örneklerin toplandığı noktaları gösteren profil çizimi (Özbaşaran, Duru ve Uzdurum, 2018, fig. 3'ten uyarlanmıştır).

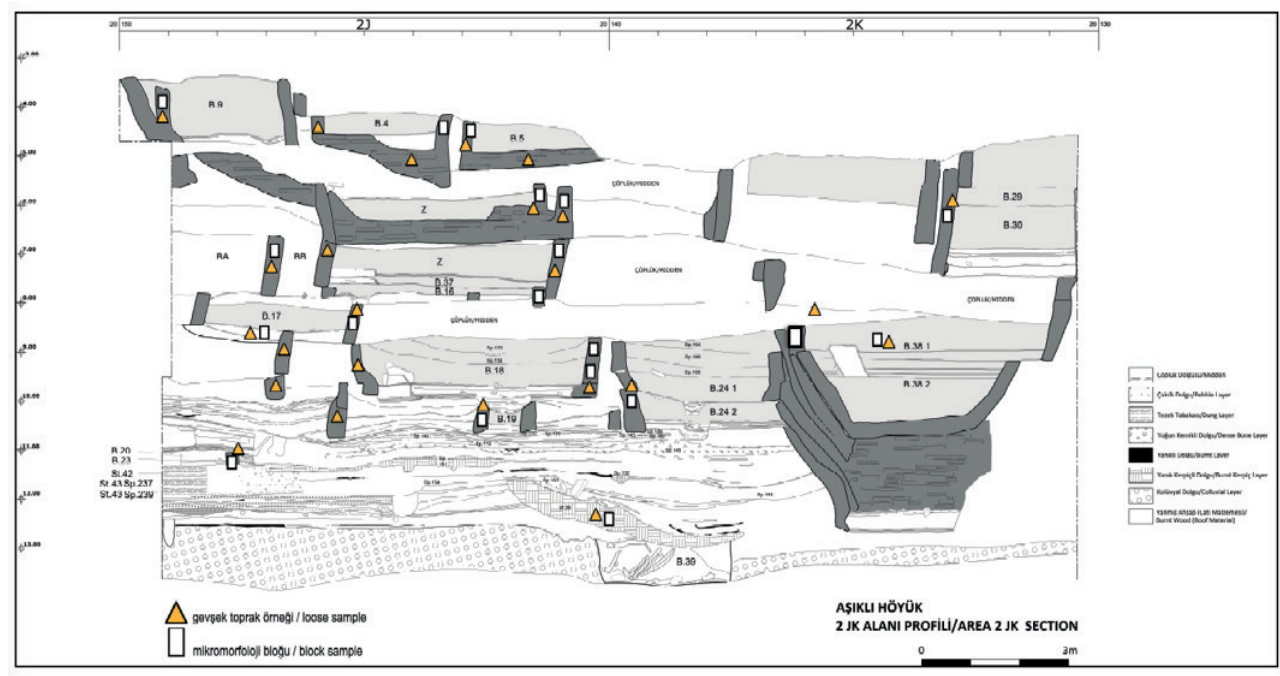

Şekil 3. 9. binyıl ortası ve 8. binyıl ilk çeyreği, 2JK Alanı, gevşek ve kesilmiş örneklerin toplandığı noktaları gösteren profil çizimi (Özbaşaran, Duru ve Uzdurum, 2018, fig. 22'den uyarlanmıştır). 


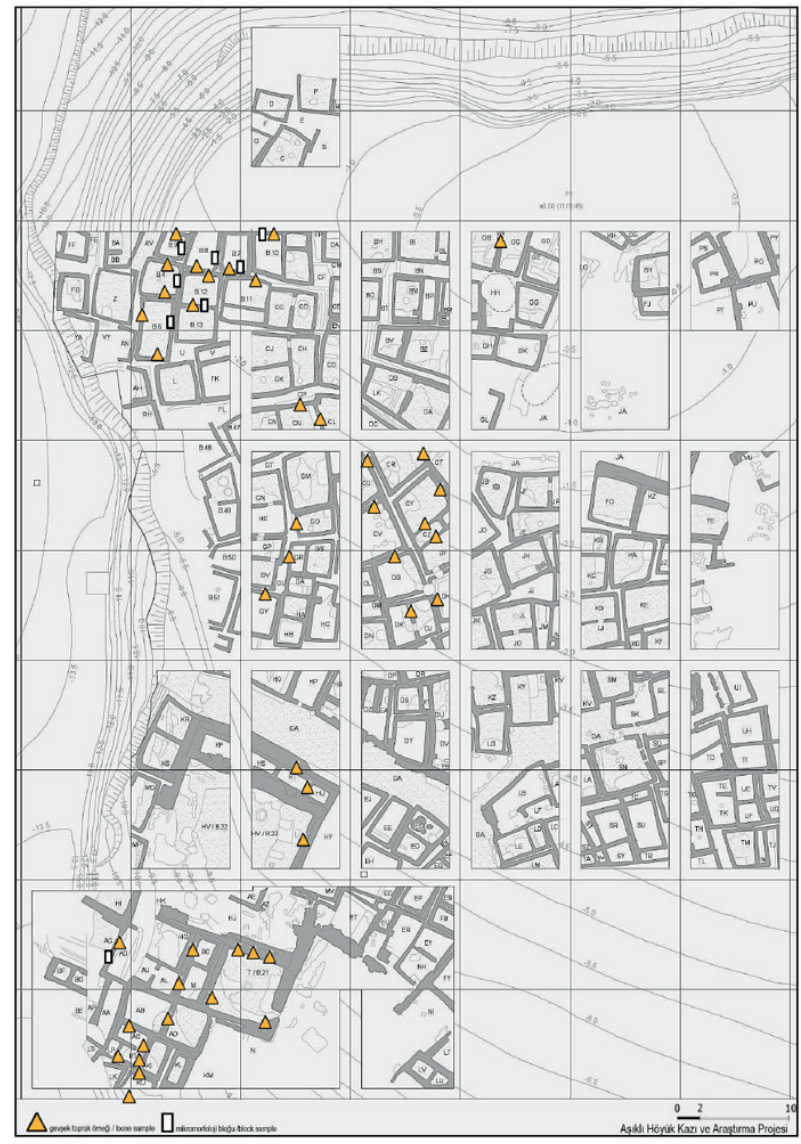

Şekil 4. 8. binyıl ikinci yarısı gevşek ve kesilmiş örneklerin toplandığı noktaları gösteren yerleşme planı. Kuzeyde konut alanı, güneybatıda özel amaçlı yapılar alanı görülmektedir (Özbaşaran, Duru ve Uzdurum, 2018, fig.1'den uyarlanmıştır). 

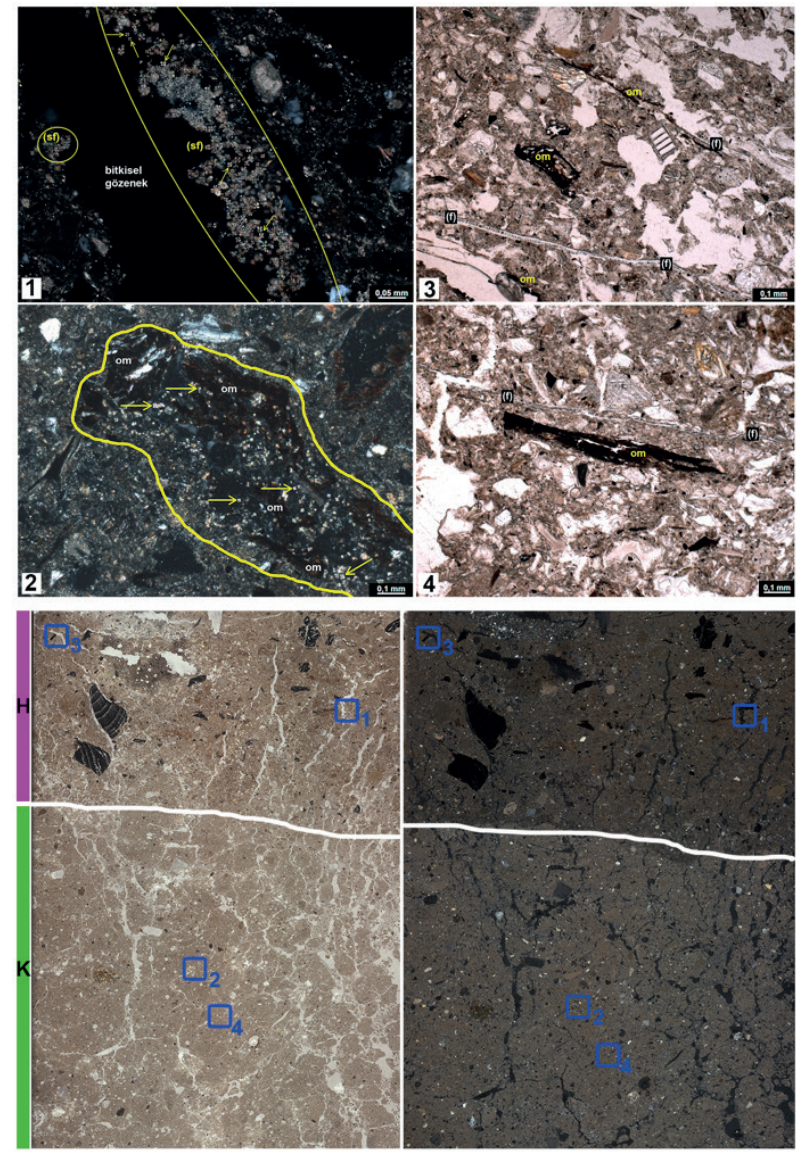

Şekil 5. Mikromorfoloji analizleri ile kerpiç (k) ve harçlarda (h) tanımlanan dışkı sferülitleri (sarı oklar), sferülit birikintileri (sf), fitolitler (f), bitkisel gözenekler ve humuslaşmış organik malzemelerin (om) mikro-bağlamını gösteren ince kesit mikroskop görüntüleri. Dışk1 sferülitleri ve sferülit topakları bitkisel gözenekler içerisinde bulunur ve organik malzemeler ile iç içedir (1) (XPL). Humuslaşmış organik malzemeler ve sferülitlerin bazıları yanmıştır (2) (XPL). Harçlardaki fitolitler humuslaşmış organik malzemeler ile karışmış halde konumlanır (3) (PPL). Bu konumlanma kerpiçlerde de gözlemlenir (4) (PPL). 


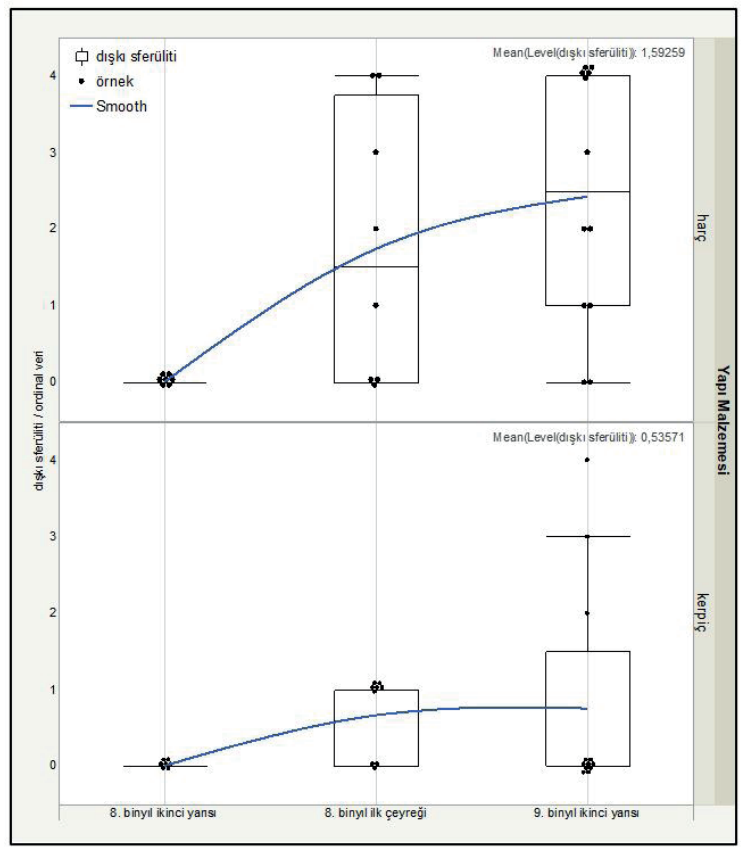

Şekil 6. Yapı malzemelerindeki dışkı sferüliti miktarının zaman içerisindeki değişiminini gösteren ince kesit analiz sonuçları. Diyagram, ordinal veri oluşturduktan ve Kruskal Wallis ve

Dunn's metodu ile çoklu karşılaştırma testi yapılarak hazırlanmıştır.

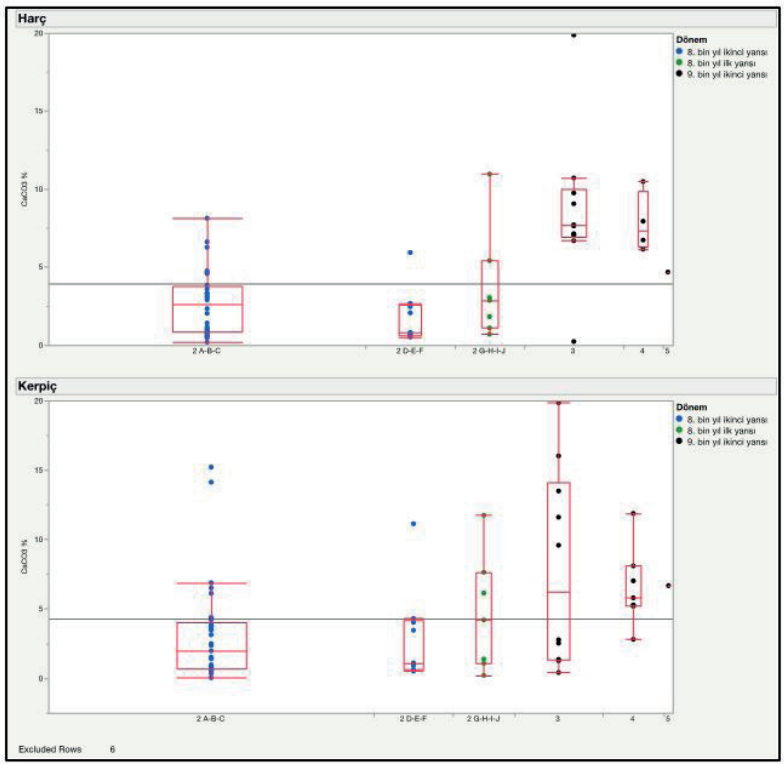

Şekil 7. Harç ve kerpiçlerdeki kalsiyum karbonat (CaCO3) miktarının yüzdesel olarak zamansal değişimini gösteren kalsimetre sonuçları. 


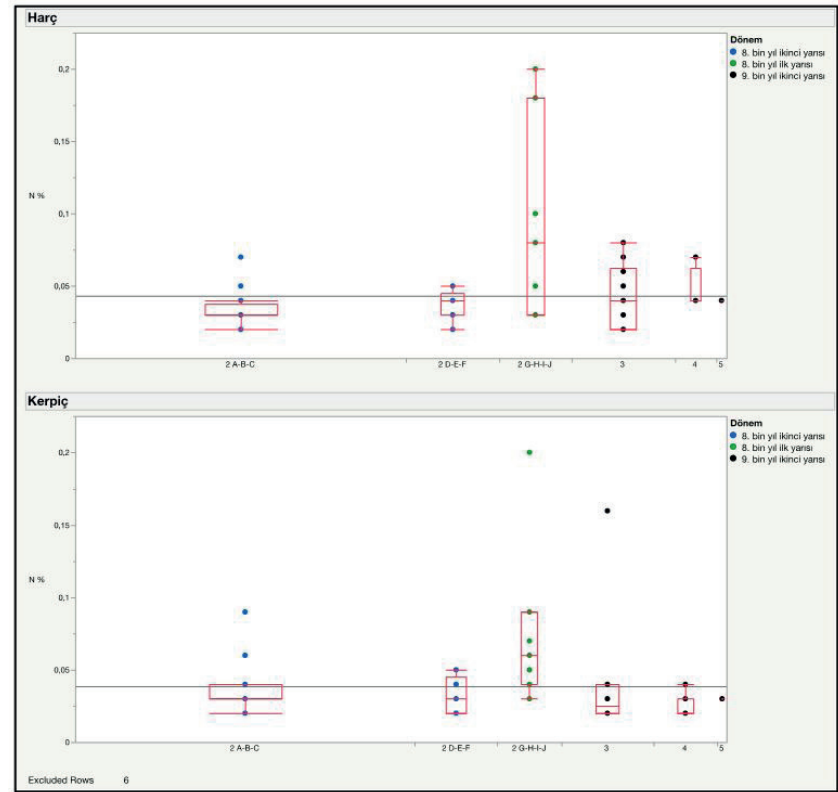

Şekil 8. Harç ve kerpiçlerdeki azot (N) miktarının yüzdesel olarak zamansal değişimini gösteren element analizi sonuçları.

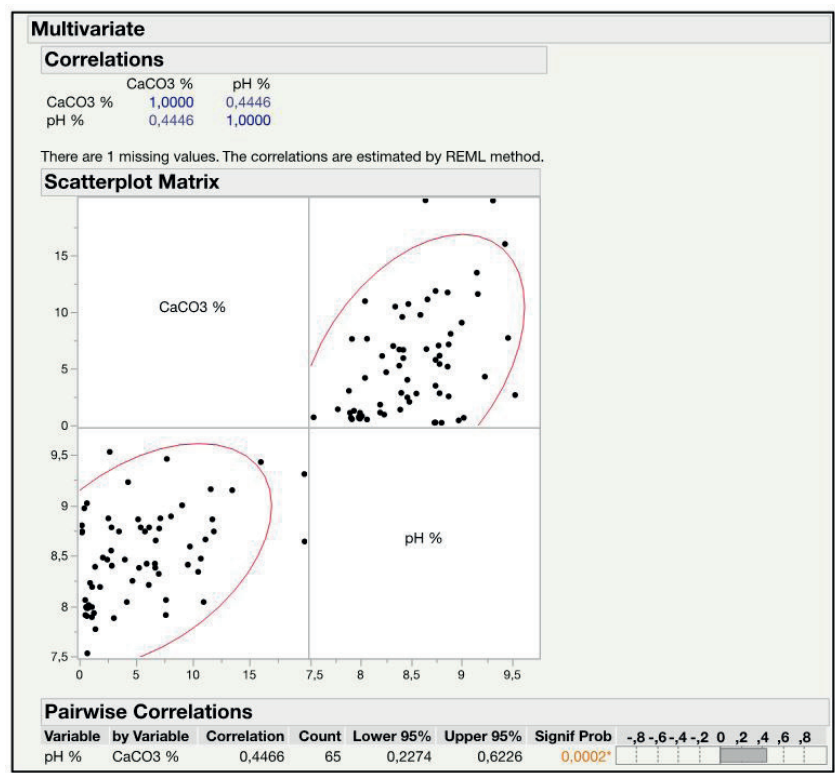

Şekil 9. İkili korelasyon testi ile $\mathrm{pH}-\mathrm{CaCO}_{3}$ arasında korelasyonun yüksek olduğu saptanan kerpiç ve harçlar. 


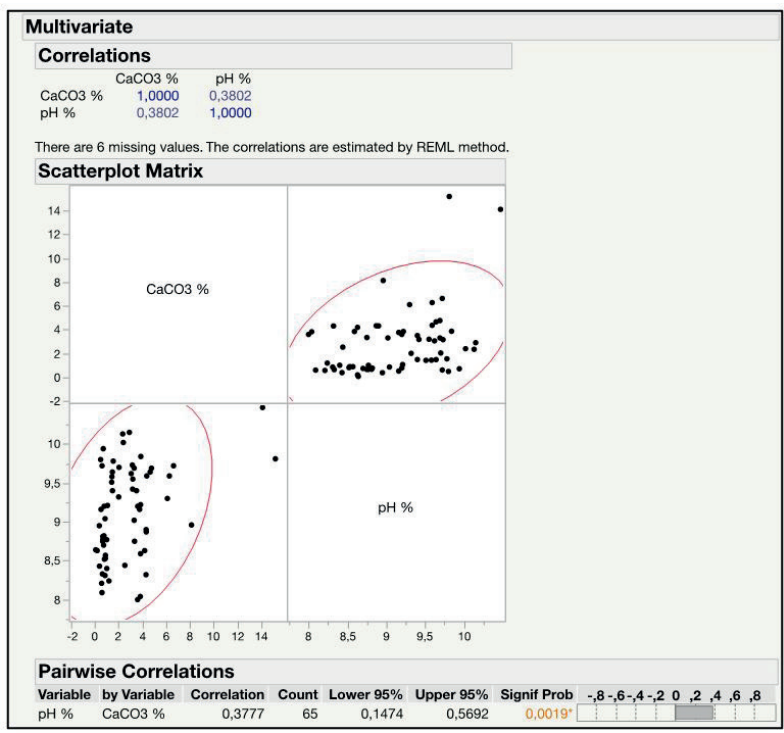

Şekil 10. İkili korelasyon testi ile $\mathrm{pH}-\mathrm{CaCO}_{3}$ arasında korelasyonun düşük olduğu saptanan 8. Binyıl ikinci yarısına tarihlenen kerpiç ve harçlar.

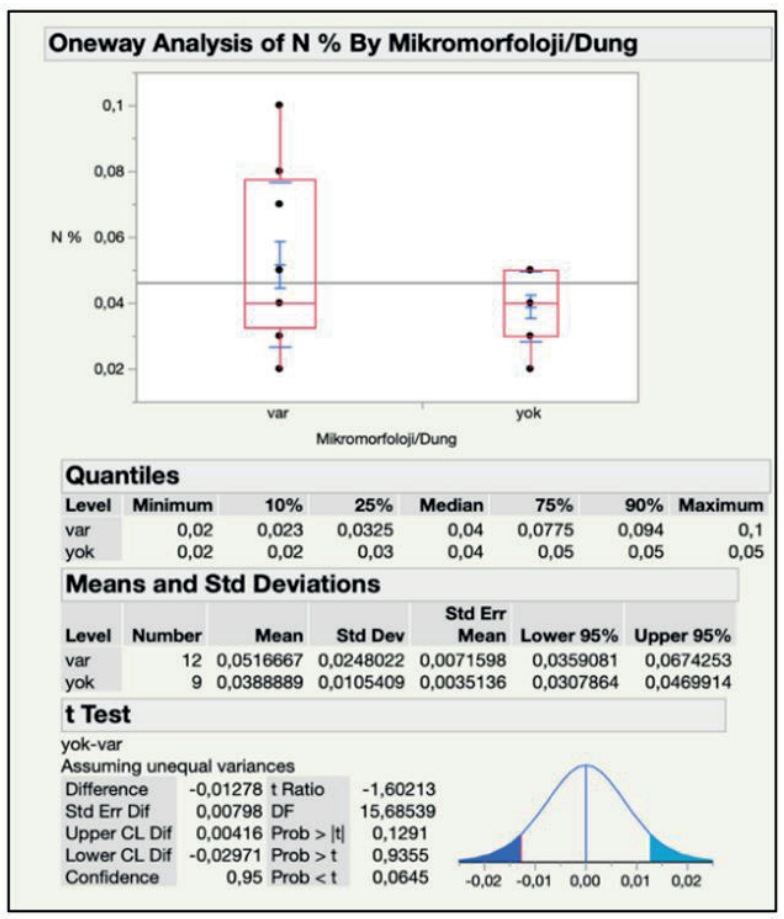

Şekil 11. Hayvan dışkısı içeren ve içermeyen harçlar ile azot yüzdesi arasındaki ilişkiyi gösteren tek yönlü T-test sonuçları. Hayvan dışkısı olan harçlarda azot miktarı yüksektir. 


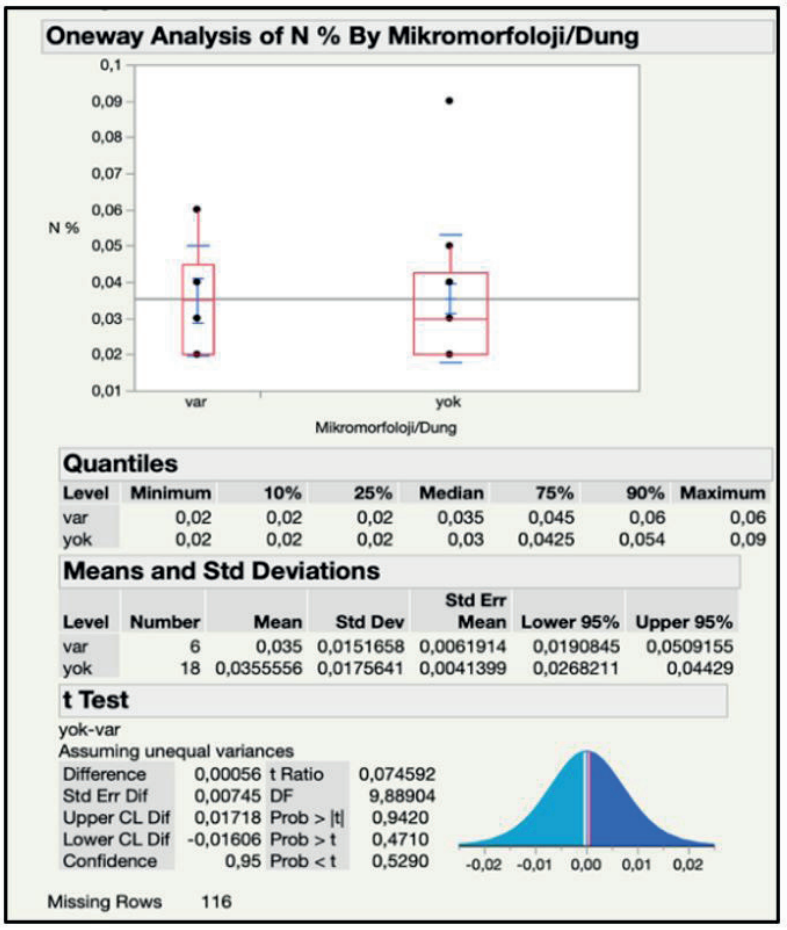

Şekil 12. Hayvan dışkısı içeren ve içermeyen kerpiçler ile azot yüzdesi arasındaki ilişkiyi gösteren tek yönlü T-test sonuçları. Hayvan dışkısı içeren ve içermeyen kerpiçlerdeki azot miktarı birbirine yakındır.

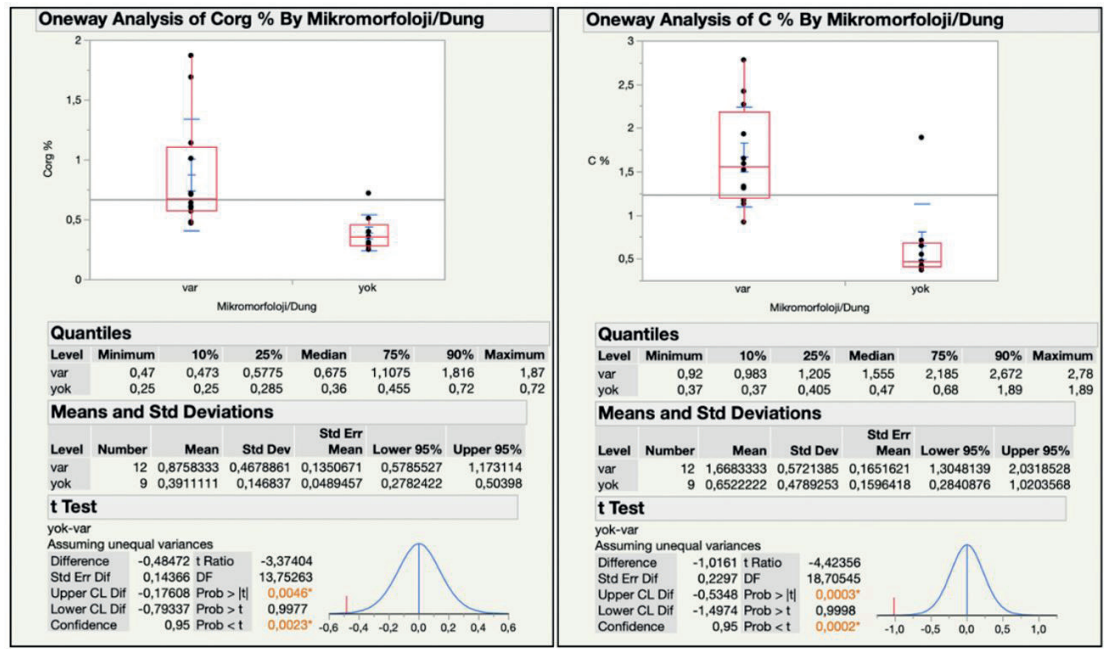

Şekil 13. Hayvan dışkısı içeren ve içermeyen harçlar ile organik karbon (solda) ve hayvan dışkısı içeren ve içermeyen harçlar ile karbon (sağda) arasındaki ilişkiyi gösteren tek yönlü T-test sonuçları. Hayvan dışkısı içeren harçlarda $\% \mathrm{C}_{\text {org }}$ ve $\% \mathrm{C}$ daha yüksektir. 


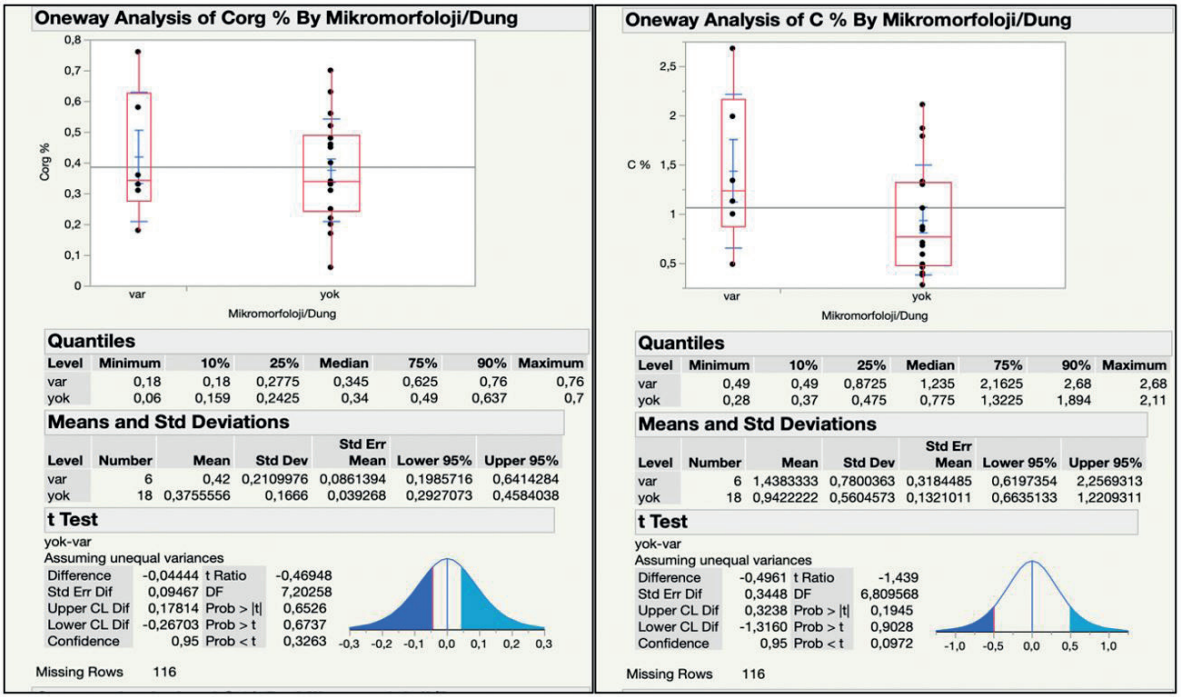

Şekil 14. Hayvan dışkısı içeren ve içermeyen kerpiçler ile organik karbon (solda) ve hayvan dışkısı içeren ve içermeyen kerpiçler ile karbon (sağda) arasındaki ilişkiyi gösteren tek yönlü

T-test sonuçları. $\% \mathrm{C}_{\text {org }}$ ve $\% \mathrm{C}$ ile hayvan dışkısı içeren ve içermeyen örnekler arasında belirgin bir farklılık görülmemektedir.

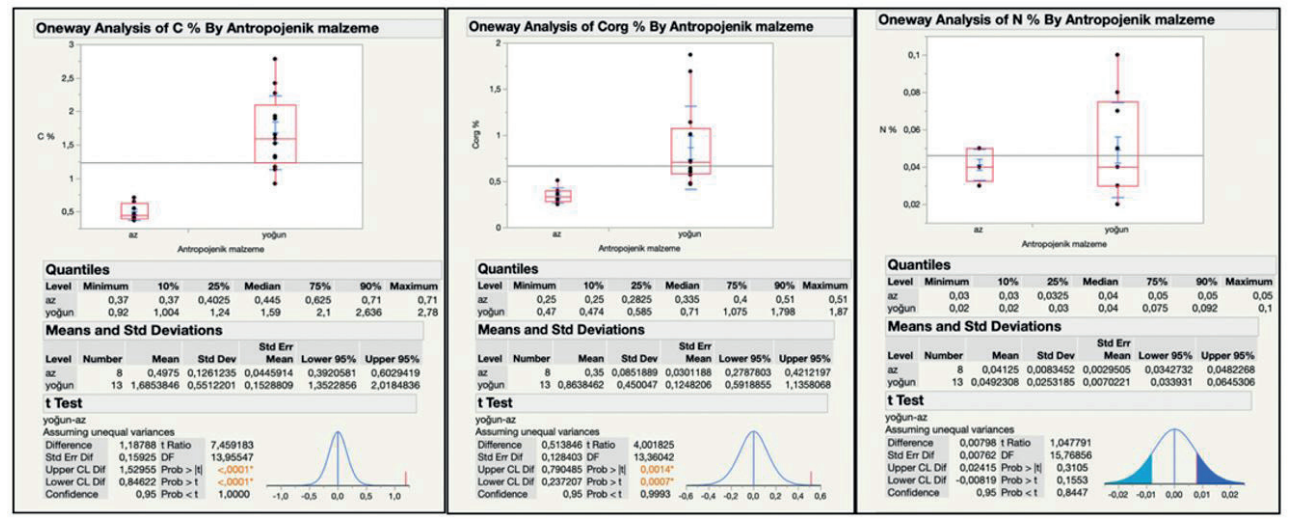

Şekil 15. Harçlarda antropojenik malzeme yoğunluğu ile karbon, organik karbon ve azot ilişkisini gösteren tek yönlü T-test sonuçları. Daha yoğun antropojenik malzeme içeren örneklerde karbon (solda) ve organik karbon (ortada) oranının da yüksek olduğu görülür. Azot ile az ya da yoğun miktarda antropojenik malzeme içeren harçlar arasındaki ilişki ise düşüktür (sağda). 


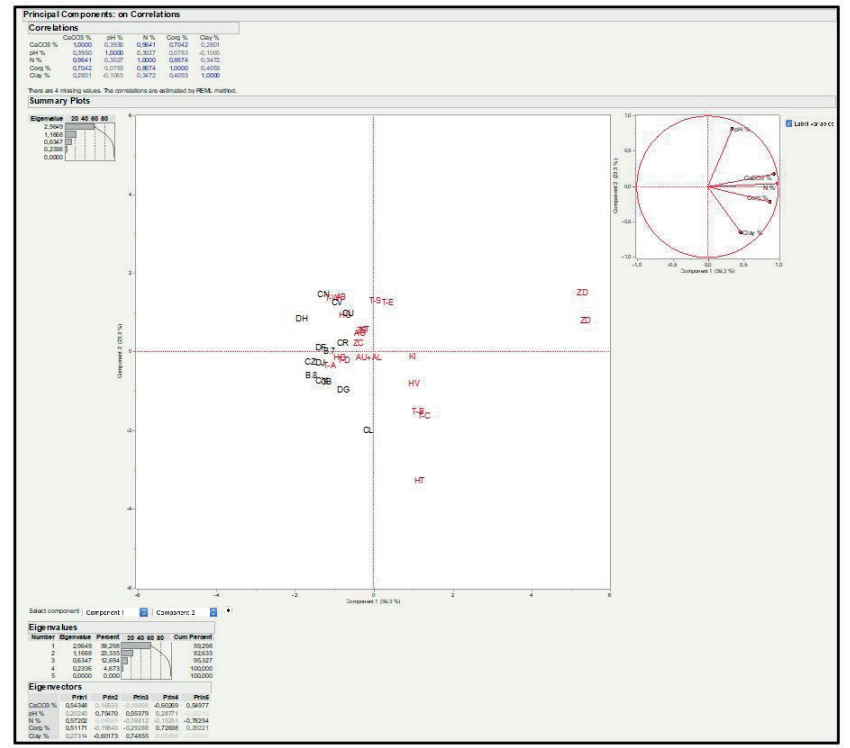

Şekil 16. Konut alanı (siyah) ve özel amaçlı yapılar alanındaki (kırmızı) kerpiçlerin pH değeri, kil $\mathrm{CaCO}_{3}, \mathrm{C}_{\text {org }}, \mathrm{N}$ miktarı (\%) değişkenleri kullanılarak yapılan temel bileşen analizi sonuçları. Özel amaçlı yapılar alanındaki kerpiçlerde $\mathrm{C}_{\text {org }}, \mathrm{CaCO}_{3}$, kil ve azot miktarının konut alanındakilerden daha yüksek olduğu görülmektedir.

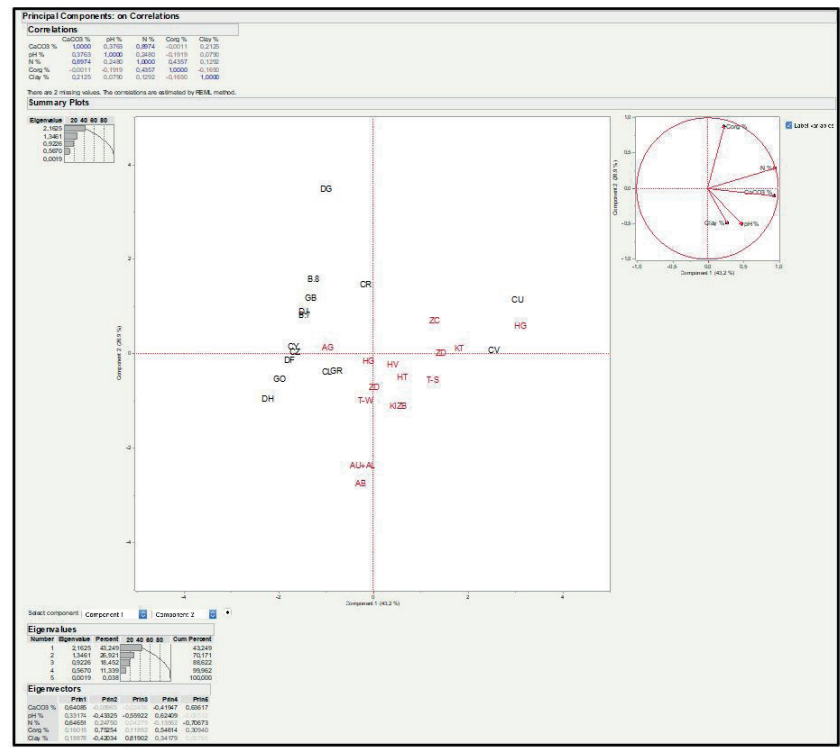

Şekil 17. Konut alanı (siyah) ve özel amaçlı yapılar alanındaki (kırmızı) harçların pH değeri, kil $\mathrm{CaCO}_{3}, \mathrm{C}_{\text {org }}, \mathrm{N}$ miktarı (\%) değişkenleri kullanılarak yapılan temel bileşen analizi sonuçları. Özel amaçlı yapılar alanındaki harçlarda azot ve $\mathrm{CaCO}_{3}$ miktarının konut alanındakilerden daha yüksek olduğu görülmektedir. $\mathrm{C}_{\text {org }}$ yüzdesinde ise belirgin farkl1l1k bulunmaz. 